\title{
RESURRECTING ISLAM OR CEMENTING SOCIAL HIERARCHY?: REEXAMINING THE CODIFICATION OF "ISLAMIC" PERSONAL STATUS LAW
}

\author{
Haider Ala Hamoudi \\ Table of Contents
}

I. INTRODUCTION 329

II. The Curious EMERgence of the Draft JA'FARI Personal Status Code 336

A. Historic Shi'i Demands Respecting Personal Status.................................336

B. The Emergence of the Ja'fari Personal Status Code of 2014 ....................340

III. Distorting the Doctrine and Managing the Divide: Marriage And the

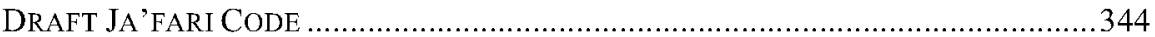

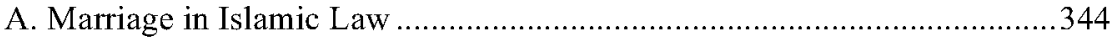

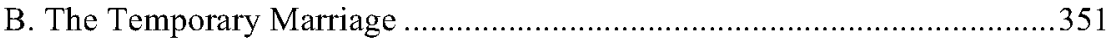

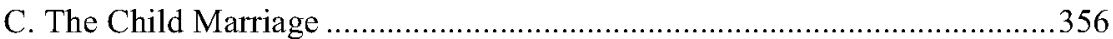

1. Child Marriage in the Traditionalist, Juristic Texts ...........................356

2. Child Marriage in the Draft Ja'fari Code ............................................ 361

IV. REORDERING THE ISLAMIC LAW HIERARCHY: TRIBES OVER JURISTS ............ 364

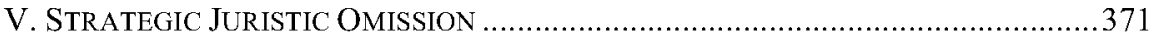

A. On Islamic Slavery and the Nature of Juristic Omission .........................371

B. On Strategic Juristic Omission and Female Genital Mutilation.................376

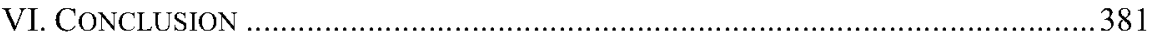

\section{INTRODUCTION}

It is obvious that Muslim liberals whose commitments are both to the religion of Islam and to core liberal values have a problem with the codification of the more traditionalist forms of the shari' $a{ }^{1}$ This is particularly, but not

Associate Professor of Law and Associate Dean of Research and Faculty Development, University of Pittsburgh School of Law. The author would like to thank Sherman Jackson, Ahmad Atif Ahmad, Clark Lombardi, Andrew March, Mohammad Fadel, Asifa Quraishi, Ali Reza Bhojani, and Kecia Ali for their generous comments and support. All errors are the author's alone.

Andrew F. March provides an excellent description of liberal values and the constraints they impose on citizens of a liberal state in his own discussions of Islam and liberalism. In his words: 
exclusively, true in the area of personal status, encompassing family law, wills, and inheritance. ${ }^{2}$ Traditionalists working within the historic schools of Islamic law developed rules for marriage that required a woman's sexual obedience to her husband, ${ }^{3}$ permitted a father to compel his child into marriage, ${ }^{4}$ and enabled a man to unilaterally end his marriage to his wife without court involvement. ${ }^{5}$ Muslim

There is very little disagreement among liberals (or even Western political theorists critical of liberalism) about what [liberalism] entails and what types of practices nonliberals are expected to endorse through their doctrines: Substate groups cannot draw on religious or cultural authority to prevent individuals from leaving a group, cannot prevent children from becoming aware of other forms of life in the society and from gaining the skills to survive in it, cannot coercively impose marital decisions on family members, cannot do certain things to their children that are physically harmful (like female genital mutilation or depriving children of urgent medical attention), and cannot punish members in certain ways for dissenting from or criticizing communal authority. Simply put, liberalism establishes a certain range of civil rights and liberties for all citizens and does not recognize the right of any cultural or religious authority to deprive its members of these rights any more than it does the state...

ANDRew F. March, Islam and Liberal Citizenship: THe SeArch for an OVERLAPPING CONSENSUS 98 (2009) (citation omitted).

March's project involves an inquiry into whether or not there is sufficiently overlapping ground between liberalism and Islam that a Muslim committed to the more traditional understandings of the shari'a could nevertheless find grounds in Islamic law for a doctrine of citizenship in a non-Muslim liberal society. Id. at 102. That worthy endeavor is distinct from the point made in this Article, which is that the codification of the traditionalist rules of the shari'a are deeply problematic to a liberal. In other words, to concretize the matter, there is a difference between asking whether a Muslim can support a non-Muslim liberal state that would permit a coreligionist to leave the faith, and whether a liberal, Muslim or otherwise, could support a law that sought to criminalize apostasy. The former inquiry, which is March's, is quite interesting and worthy of study. As to the latter question, as the main text notes, anyone committed to liberal values as defined above would necessarily answer in the negative. The matter is so obvious as to be nearly definitional.

2 See Kristen A. Stilt, Islamic Law and the Making and Remaking of the Iraqi Legal System, 36 GEO. WASH. INT'L L. REV. 695, 731 (2004) (describing personal status as encompassing "marriage, divorce, child custody, inheritance, and other family-related matters").

3 Lama Abu-Odeh, Modernizing Muslim Family Law: The Case of Egypt, 37 VAND. J. TRANSNAT'L L. 1043, 1063-64 (2004).

Judith TUCKeR, WOMEn, FAMILY AND Gender In IsLAMiC LAW 43 (2008) ("All legal schools agreed that a father had a right to marry [a bride in her legal minority] to whomever he chose without consulting her; the father enjoyed similar rights to marry off his minor sons."). This is discussed more extensively, see infra Section III.C.

$5 \quad I d$. at 86 (" $[I] \mathrm{n}$ its baldest form, a man could end his marriage simply by pronouncing a formula of divorce, after which his wife must wait a statutory period ... 
liberals, who advocate against such rules, oppose traditionalist efforts to codify them. In doing so, Muslim liberals articulate alternative understandings of sacred Islamic texts that are reformist and liberal, and yet reverential of Islam and Islamic values. ${ }^{6} \quad$ These articulations are entirely plausible, refute Islamophobic movements that seek to reduce Islam to a caricature, ${ }^{7}$ and deserve more attention than they receive. It is also fair to note, however, that the articulated Islamic vision seems as influenced by exogenous commitments to liberal values as it is to Islam itself.

The same set of perceptions and assumptions respecting dual commitments does not seem to exist with Muslim social conservatives - a term I use to refer to those who are interested in preserving traditional hierarchies and authorities within Islamic societies and who therefore oppose significant changes to the existing social order. $^{8}$ The presumption seems to be that only an

before the divorce was automatically finalized. There was no role for the court, no possibility of contest by the wife, and only limited obligations imposed on the husband for payment of any dower he owed and temporary support of his wife while she waited for the divorce to be finalized.").

6 For just a short sampling of the formidable literature on this subject, see generally

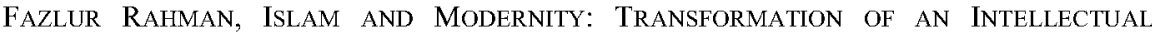
TRADITION (1982) (articulating an ambitious reformation of Islam's intellectual traditions in order to render them compatible with modernity); ABDULLAHI AHMED AN-NA'IM, TOWARD AN IsLAMic ReFormation: CIVIL LibERTIES, HuMAN Rights AND INTERNATIONAL LAW (1st ed. 1996) (developing a theory of sacred text that focuses less on specific rules and more on broader principles); Kecia Ali, SeXual Ethics \& Islam: Feminist Reflections on QUR'AN, HADITH AND JURISPRUDENCE (2006) (offering a searching look at the extent to which Islam may be made compatible with modern conceptions of women's rights); AMINA WADUd, QuR'AN AND WOMAN: REREADING THE SACRED TEXT From a WOMAN's PerspeCtIVE (1999) (suggesting that the Qur'an, when read from a perspective other than the traditional and patriarchal, is not as gender discriminatory as it is often perceived to be).

7 In the words of the respected scholar of Islam, John L. Esposito:

It is not difficult to find material that emphasizes selective analyses and events in the Muslim world, material which is crisis oriented and headline-driven, fueling stereotypes, fears and discrimination. Islam's portrayal as a triple threat (political, civilizational and demographic) has been magnified by a number of journalists and scholars who trivialize the complexity of political, social and religious dynamics in the Muslim world.

John L. Esposito, Foreword to NATHAN LEAN, IsLAMOPHOBIA INDUSTRY: How THE RigHT MANUfACTURES FEAR OF MUSLIMS, xi (2012).

8 I am less concerned in this Article about whether such social conservatives are also political conservatives. That is to say, a Muslim social conservative may be a tribal leader with little interest in exercising control over the state, or he or she may be a member of an Islamist political party who explicitly seeks political power to ensure that traditional social hierarchies are maintained. Both fit within the rubric of "social conservative" as defined in the main text. I certainly do not use of the terms "liberal" and "conservative" to 
unshakeable commitment to traditionalist understandings of the shari'a motivates Muslim social conservatives, as opposed to the liberal, for whom Islam and liberalism are equally motivating. Hence, media references to "strict" Islamic law refer to a panoply of positions that socially conservative forces within Islamic societies advance, including the closing of movie theaters, ${ }^{9}$ the severing of hands of businesspeople who operate without a license, ${ }^{10}$ and even the ripping of gold teeth from the mouths of citizens. "Literalism" has come to mean the rejection of all Western influences ${ }^{12}$ and, of course, international terrorism, justified through jihad. ${ }^{13}$ It should be obvious that none of the above is a "strict" or "literal" application of religious text, but rather all are interpretations of varying plausibility of original sources and traditional, historic commentaries. Could anyone really believe that seventh-century sacred sources, or medieval interpretations of them, have anything "strict" or "literal" to say about flying a plane into a skyscraper?

Once so framed, the problem for the liberal or the reformer is rather obvious. After all, if the conservative strictly follows the traditionalist readings of the sacred texts verbatim, then the liberal is left working out a contextual (as opposed to literal) and flexible (as opposed to strict) interpretation influenced by foreign ideas. In other words, the conservative follows the Word strictly and is "pure," 14 while the liberal manipulates it to harmonize it with other values held dear. The liberal is therefore at a distinct disadvantage when seeking to persuade the committed believer of the plausibility of any given liberal position in light of its perceived contamination.

Using a particularly salient example of legislation initiated very recently, the primary purpose of this Article is to demonstrate that it is a deep and fundamental mistake to presume that conservative commitment is the same as

refer in any way to contemporary political disputes in the United States, which bear no relevance here.

9 Movies, Music Banned, Pittsburgh Post-Gazette, July 15, 1996, at A4.

10 Ghaddafi Reinterprets Strict Islamic Law, WASH. TIMES, May 25, 1994, at A13.

11 Somalia: Islamists Pulling Teeth from 'Sinners', OtTAWA Citlzen, Aug. 11, 2009, at A6.

12 See Haider Ala Hamoudi, Are Salafis "Literalists"?, ISLAMIC LAW In OUR Times (Sept. 20, 2012), http://muslimlawproforg/2012/09/are-salafists-literalists/.

i3 Martin Regg Cohn, Inoculated Against Religious Radicalism; Mainstream Disenchantment With Fundamentalism Is Clear In The World's Largest Muslim Nation, TORONTO STAR, Feb. 27, 2005, at A12.

14 "Pure" is another term used to describe Muslim social conservatives. See, e.g., Ali Allawi, The Crisis of Islamic Civilization 250 (2009) (describing the manner in which Rashid Ridha turned against "reformed Islam" later in his life and opted to endorse the "purer, Salafi variety"). Allawi does not hesitate to criticize the ultraconservative, Salafist philosophies elsewhere in his work as hardly in keeping with Islamic intellectual traditions. Id. at 38-39. When even a bold and iconoclastic intellectual like Allawi uses the word "pure" to describe Salafism, juxtaposing it against Ridha's earlier reformist ideas, it is apparent that there is something wrong with our nomenclature. 
fealty to any pure conception of religious law. Specifically, this Article shows that even within the area of personal status, where Muslim social conservative commitment to shari' $a$ is strongest, there are significant divergences between traditionalist expectations of Muslim social conservatives and the actual rules set forth in the doctrine. Moreover, where such divergences exist, legislative drafters defer to the Muslim social conservative expectations at the expense of doctrine. This is important, because it explodes the false equivalence between conservatism and religious commitment. If Muslim social conservatives cannot remain committed to the most traditional and historic renderings of personal status rules, to such an extent that state law must meet their demands rather than realize religious law, then how can anyone realistically contend that adherence to traditional understandings of religion motivates them exclusively? In the end, is the Muslim social conservative not engaged in the same practice as the Muslim liberal - molding, shaping, manipulating, and ignoring various pieces and parts of doctrine to render it compatible with a series of preexisting commitments that are only partly religious in their origins? The result does not necessarily privilege liberal readings over conservative ones, but at the very least it puts them on a level playing field and permits us to see the contentions as driven more by ideological commitment than by doctrine. In other words, the Muslim social conservative prefers existing hierarchies and structures, and the Muslim liberal seeks to change them. Neither of those preferences necessarily has much to do with fealty to shari'a.

To demonstrate this point, I use the draft Ja'fari Personal Status Code of Iraq, approved by the Iraqi cabinet in the spring of 2014 and sent to the legislature for proposed enactment shortly thereafter. ${ }^{15}$ Though never made into law given the subsequent rise of the Islamic State of Iraq and Syria ${ }^{16}$ as well as elections that led to the designation of a new Prime Minister, ${ }^{17}$ the draft is particularly relevant to the themes of this Article for two reasons. First, it is a result of decades-long efforts by leaders of that part of Iraq's population who follow the Shi'i sect of Islam $^{18}$ to enact a Personal Status Code specific to the Shi'i community that

15 Suadad Al-Salhy, Iraqi Women Demonstrate Against Proposed Iraqi Law in Iraq, REUTERs (Mar. 8, 2014), http:/www.reuters.com/article/2014/03/08/us-iraq-womenislam-idUSBREA270NR20140308.

16 The Islamic State of Iraq and Syria (ISIS) took control of Mosul in the summer of 2014, a few months after the Ja'fari Personal Status Code was introduced. See Martin Chulov, ISIS Insurgents Seize Control of Iraqi City of Mosul, GUARDIAN (June 10, 2014), http://www.theguardian.com/world/2014/jun/10/iraq-sunni-insurgents-islamic-militantsseize-control-mosul.

Haider al-Abadi was named the Prime Minister of Iraq on August 11, 2014, replacing Nouri al-Maliki, who had held the position previously and was quite reluctant to give it up. Adam Taylor, Meet Haider al-Abadi, The Man Named Iraq's New Prime Minister, WASH. POST (Aug. 11, 2014), http://www.washingtonpost.com/blogs/world views/wp/2014/08/11/meet-haider-al-abadi-the-man-named-iraqs-new-prime-minister/.

18 The primary difference between the Shi'a and the Sunnis concerns the assumption of political and religious authority following the death of the Prophet 
adheres more closely to Shi'i rules than the existing Personal Status Code does. ${ }^{19}$ This renders adherence to traditional rules in the draft Code important. Second, unlike their Sunni counterparts, Shi'i jurists operating in the seminaries located in the Holy City of Najaf retain broad levels of legitimacy and authority respecting the content of shari'a. ${ }^{20}$ This renders the traditional rules relatively easy to locate. If there were a law, then, where one would expect very close and faithful adherence to traditional rules, it would be in the draft of the Ja'fari Personal Status Code. Departures from the rules should be both obvious (given how easy it is to identify the Shi'i rules) and unjustifiable (given that the very purpose of the project is to enable the Shi'a to live by their traditional rules).

And yet, in any number of cases, as the Article makes clear, the draft law diverges sharply from the juristic rules clearly established in Najaf. In each case, the divergence appears to lie in an area where the core constituency of Shi'i social conservatives - who might be expected to support such draft legislation, and whose electoral support the drafters were soliciting in preparing the draft had expectations and commitments that stood in stark contrast to those of the jurists. Thus, it is quite clear that the drafters of the Ja'fari Personal Status Code did not make any real effort to realize some pristine form of religious doctrine. Rather, they presented a transmogrified version designed to meet the expectations of modern Muslim social conservatives. This does not make it per se illegitimate, to be clear. Rather, it is no less and no more legitimate than the vision of the liberal, whose preferences lie not in preserving traditional hierarchies and modalities of authority, but in upending them. The point, ultimately, is that it is dangerous and hardly conducive to religious reform within the Islamic tradition to privilege the conservative position as being a purer form of shari'a.

Part II provides some necessary context respecting the decades-long Islamist Shi'i demand for the repeal of the existing Iraqi Personal Status Code and its replacement with a law that reflects the juristic rules more closely. It also describes the specific political conditions prevailing in Iraq in the spring of 2014 that caused the draft Code to be recommended for enactment. Having provided that context, Parts III and IV demonstrate the manner in which the draft Code deviates from doctrine, specifically to conform to the expectations of the Muslim social conservative constituency that was expected to support it. Part III is devoted to the draft Code's treatment of two major, long standing aspects of Shi'i law with deep pedigree which have proved problematic in modernity. The first is

Muhammad. The Shi'a believe that during his lifetime, the Prophet Muhammad specifically designated his cousin and son in law Ali ibn Abi Talib as the infallible leader of the Muslim community after his death. The Shi' a further believe that there are 12 such infallible leaders, referred to as Imams. Robert Gleave, Inevitable Doubt: Two THEORIES OF SHI'I JURISPRUDENCE 1 (2000).

19 This is described in detail in Section I.A, infra.

20 Haider Ala Hamoudi, Money Laundering Amidst Mortars: Legislative Process and State Authority in Post-Invasion Iraq, 16 TRANSNAT'L L. \& CONTEMP. Probs. 523, 539 (2007) [hereinafter Hamoudi, Money Laundering]. 
the favorite whipping boy of Shi'i legal doctrine: the temporary marriage. ${ }^{21}$ The second is child marriage, which is permitted across both Sunni and Shi'i traditional schools. $^{22}$ The drafters all but ignored the first of these, while they not only embraced, but indeed also expanded, the second of them far beyond traditional and doctrinal boundaries. The only possible explanation for such an otherwise odd result is that socially conservative forces do not engage in or support the idea of temporary marriage, and indeed are embarrassed by its formal legality, while many (though certainly not all) support, and in a few cases practice, child marriage.

Part IV turns to an even starker form of deference on the part of the drafters of the Code by showing that where the interests of socially conservative institutions such as tribes conflicted with those of the jurists, the drafters privileged the tribes over the jurists specifically on the determination of the content of Islamic law. This is quite ironic given that the core objection of the existing Personal Status Code was that it stripped the jurists of their power to determine Islamic law and gave it to lawmakers instead. ${ }^{23}$

From the distortions of the draft Code described in Parts III and IV, the Article then turns to juristic omissions and distortions in Part V. Part V thus addresses other parts of historic doctrine that have proved problematic and controversial in contemporary times, specifically slavery and female genital mutilation. However, unlike the subjects of Parts II and III, these are areas where jurists have themselves sought to manage the conflict between the historic rules and the expectations of their devout and socially conservative constituencies by omitting or distorting the historic rules, so as to avoid reciting a rule that is sure to earn a hostile reception. In these cases, the draft Code had something of an easier time, given that it could merely replicate the compendia of contemporary jurists and claim faithfulness to the traditionalist rules of the Shi'a that did not in fact exist.

In sum, this Article demonstrates that the draft Personal Status Code is not the enactment of historic Shi'i religious doctrine so much as it is the realization of the ideological commitments of the substantial portion of the Iraqi Shi'i community that is socially conservative. The Article concludes by arguing that unless the substantial, presumed equivalence between Muslim social conservatism and Islamic law doctrine is severed, it will be nearly impossible to free Islam from the constrictive shackles of the socially conservative commitments with which it is currently so closely, and falsely, identified.

21 The temporary marriage is discussed in Part II.A. As for its repeated denunciations among Sunni polemicists, see, e.g., Shaykh Muhammad Saalih al-Munajjid, Mut'ah Marriage and the Refutation of Those Raafidis who Permit It, ISLAM QUESTION AND ANSWER (Dec. 17, 2002), http://islamqa.info/en/20738 (describing the Shi'a as "following their own whims and desires" in permitting the temporary marriage).

22 TUCKER, supra note 4 , at 43.

23 This point is described in some detail in Part $\mathbf{I}$. 


\section{THE CURIOUS EMERGENCE OF THE DRAFT JA'FARI PERSONAL STATUS CODE}

\section{A. Historic Shi'i Demands Respecting Personal Status}

If there ever were a place where one would expect a modern piece of legislation to replicate almost entirely the law of the jurists, it would lie in a draft Personal Status Code designed for Iraq's Shi'a. The Shi'i political and religious leaders who represented socially conservative elements of Iraqi society spent decades calling precisely for this and for the repeal of the existing Personal Status Code in the process. In fact, the hostility between Islamist Shi'a to the existing Iraqi Personal Status Code predates the enactment of that Code. ${ }^{24}$

The Personal Status Code was written in 1959, intending to create a uniform law of personal status that would apply to all Iraqis. ${ }^{25}$ It is therefore an amalgam of sorts of different schools of thought within the Islamic tradition, Sunni and Shi'i, with the drafters of the Code selecting a rule based on what appealed the most to their left leaning progressive sensibilities. ${ }^{26}$ Hence, its rules of inheritance drew largely on Shi'i tradition, while the rules on judicial dissolution of marriage came from the Sunni, Maliki school of thought. ${ }^{27}$ Modest, but important, reforms beyond those in the juristic manuals of any school of thought were made as well, including most prominently the banning of child marriages contracted by guardians. ${ }^{28}$

The Shi'i opposition to the law, however, ran far deeper than a mere dispute over substance. In fact, most of the substantive objections that they have actually articulated over the course of decades appear safely on the margins as a practical matter. These include, for example, the fact that a Shi'i marriage does not require two witnesses in order to be valid, and yet the Personal Status Code

24 Kristen A. Stilt, Islamic Law and the Making and Remaking of the Iraqi Legal System, 36 GEO. WASH. INT'L L. REV. 695, 748-52 (2004).

25 Hamoudi, Money Laundering, supra note 20, at 543-46.

26 See $i d$. at 544 . The Code was enacted one year after a revolution in Iraq that deposed the Iraqi monarchy and instituted what was called a "republic," though in point of fact it was a dictatorship led by strongman Abdul Karim Qasim. Qasim was not a communist, but his sympathies very much lay on the political left, and he did ally with the communist party at various times during his short period of rule. MARION FAROUKSluglett \& Peter Sluglett, Iraq Since 1958: From ReVolution to Dictatorship 4951, 58, 59 (I.B. Tauris \& Co. Ltd., 2d ed. 2003).

27 See, e.g., Personal Status Law, No. 188 of 1959 (Iraq), Art. 91(2) (concerning the inheritance of daughters), Art. 43 (concerning the right of a wife to obtain a judicial dissolution of her marriage) (hereinafter Iraq Personal Status Code). For the Islamic origins of these various provisions, see MARK CAMMACK \& HAIDER ALA HAMOUDI, ISLAMIC LAW IN MODERN COURTS (forthcoming 2016) (on file with author).

28 Iraq Personal Status Code, supra note 27, arts. 8-9. See also CAMMACK \& HAMOUDI, supra note 27; Part IV.B, infra (discussing child marriage in Islamic law more broadly). 
adopts the Sunni position that a marriage is not valid without two witnesses. Therefore, should two people find themselves in a desert overtaken with unquenchable sexual desire, opponents to the existing Code argued, the law would present them with no alternatives to fornication. ${ }^{29}$ The Shi'i elite, agitating for decades against the Personal Status Code, surely do not think that this is an actual problem that arises with any degree of frequency. Even if they do, there are narrower ways of addressing it than repealing the entire Code.

Instead, the core objections to the Code run to the very conception of state control over rulemaking as it concerns personal status. ${ }^{30}$ The idea that the state, rather than the jurists, determine how many witnesses are needed to conclude a marriage strikes Shi'a Islamists as offensive and requiring repeal for no reason other than that it suggests that someone other than the jurists should be able to determine the content of personal status rules. ${ }^{31}$ By the time of the enactment of the Personal Status Code, the Shi'a may have long acquiesced to the encroachment of secularized state law into the private law realm in any number of areas from property, to contracts, to torts. ${ }^{32}$ However, the principle that personal status needs to remain firmly Islamic, and firmly juristic, continues to hold strong. Formally, the Shi'i Islamist demand is constant, and it is firm. The jurists, and only the jurists, can make the law of personal status.

Hence, even as the Personal Status Code was being promulgated a half century ago, a prominent jurist and a scion of one of Najaf's clerical families, Muhammad Bahr al-Ulum, published a widely distributed pamphlet describing the deviations from juristic rules that were part of the Personal Status Code. ${ }^{33}$ Deliberately ecumenical, Bahr al-Ulum identified deviations that would prejudice Sunnis as much as those that would prejudice the Shi'a. Thus, for example, he included as criticism the rule that an intoxicated man could not validly divorce his wife under the Personal Status Code. This is a replication of a Shi'i rule, but it diverges from the rule of the Hanafi Sunnis. Bahr al-Ulum's point was that it was no fairer to impose Shi'i rules on Sunnis (namely, in this case, the drunk Hanafi who wishes to divoree his wife) than it is to impose Sunni rules (for example, the requirement of two witnesses to a marriage) on Shi'is. ${ }^{34}$

The Personal Status Code was enacted in 1959 despite Bahr al-Ulum's criticisms. The objections to the Code nevertheless continued in circulation for some time, rising in particular with the emergence of the Shi' $i$ Islamist "Da'wa" movement in the 1970 's that sought a form of Islamic rule in Iraq. ${ }^{35}$ Saddam Hussein and his ruling, secular, Arab national Ba'ath party crushed the movement

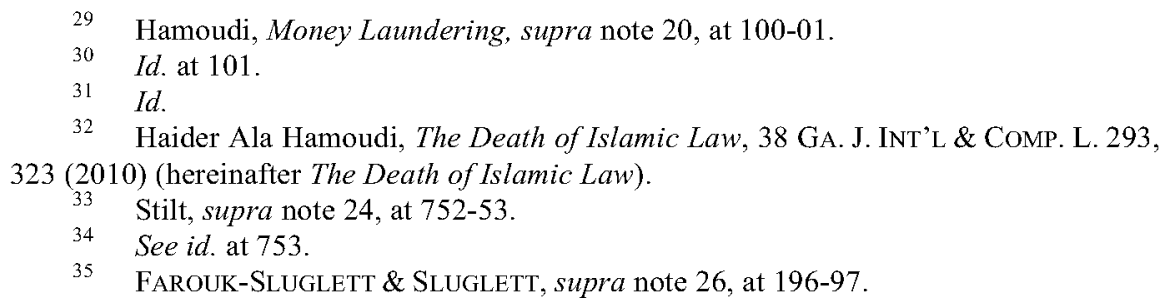


with unspeakable repression in the 1980's, after which criticism of the Personal Status Code, or any element of Iraqi law or Ba'ath rule, was silenced. ${ }^{36}$

Yet the issue of personal status continued to fester and in fact it emerged soon after the fall of Saddam Hussein, at a time when full sovereignty had not even been restored to Iraq. In December of 2003, Shi'i Islamists sought a repeal of the Personal Status Code through the enactment of a resolution that replaced it with nothing more than a reference to traditional, applicable juristic rules based on the sect of the litigants. ${ }^{37}$ The resolution was never approved by the United States - occupier at the time and ultimately it was repealed in a raucous session that ended in a walkout by the Shi'a Islamist forces. ${ }^{38}$ But, it was a harbinger of further events. After all, it was obvious to everyone even in the summer of 2003 that the United States would not remain in Iraq forever. When it left, Shi'a Islamist political power would be considerable given the seeming political predispositions of the masses of Iraq's majority Shi'a population.

The Shi'a Islamists ultimately used that political clout to include the infamous Article 41 in the final Iraq Constitution. ${ }^{39}$ That article contemplates the "freedom" of Iraqis to live by their own rules of personal status based on their "religions, sects, beliefs and choices." 40 It also indicated that this freedom is to be "organized by law," as indeed it would have to be in order to make any sense at all. ${ }^{41}$ The draft Ja'fari Personal Status Code purports to be nothing more than the organizing law called for under Article 41 for Iraq's majority Shi' a population. ${ }^{42}$

To summarize, the articulated demand for a specifically Shi'i Personal Status Code was one that insisted on the precise replication of juristic rules. It

\footnotetext{
$36 \quad I d$. at 200.

37 Stilt, supra note 24, at 751.

38 LARRY DIAMOND, SQUANDERED VICTORY: THE AMERICAN OCCUPATION AND THE BUNGLED EFFORT TO BRING DEMOCRACY TO IRAQ 172 (2005).

39 See Ashley S. Deeks \& Matthew D. Burton, Iraq's Constitution: A Drafting History, 40 CORNELL INT'L L.J. 1, 21 (2007).

40 Hamoudi, Money Laundering, supra note 20, at 102.

41 If there is to be any law respecting personal status, then that law will inevitably restrict the "beliefs and choices" of some people. Hence, the best way to read Article 41 is as being a law that permits, indeed even endorses, family law pluralism, but leaves it to the legislature to determine the precise contours of that pluralism. Id. The Federal Supreme Court of Iraq has effectively adopted that interpretation, refusing to replace or reinterpret the existing Personal Status Code in the absence of legislative action. Id. at 204-05 (discussing Federal Supreme Court of Iraq Decision 59 of 2011).

42 Stipulated Reasons, Ja'fari Personal Status Code (Iraq) (draft 2013) [hereinafter Draft Ja'fari Code] (on file with author). It should be noted that copies of the draft Code were widely disseminated throughout Iraq in the early part of 2014, and some copies remain available on the Internet. See, e.g., Al Masalah Publishes the Draft Ja'fari Personal Status Law, (May. 5, 2016, 9:37 AM), http://almasalah.com/ar/News $/ 18949 / \%$ D $8 \%$ A7\%D9\%84\%D9\%85\%D8\%B3\%D9\%84\%D8\%A9-\%D8\%AA\%D9\%86\%D8\%B4\%D8\% B1-\%D9\%86\%D8\%B5-\%D9\%85\%D8\%B4\%D8\%B1\%D9\%88\%D8\%B9-\%D9\%82\%D8 \%A7\%D9\%86\%D9\%88\%D9\%86-\%D8\%A7\%D9\%84\%D8\%A3\%D8\%AD\%D9\%88\%D8 $\% \mathrm{~A} 7 \% \mathrm{D} 9 \% 84-$.
} 
neither accepted amalgamation of juristic rules of different sects to create a uniform code, nor did it contemplate that the legislature could somehow modify, qualify, reform, or restructure juristic rules in any meaningful fashion in the area of personal status to realize broader public interest values. Whether these approaches, or others, could be justified in a modern state under any Islamic constitutional theory is a rich and deserving subject of debate elsewhere in the academic literature. ${ }^{43}$ It is also entirely irrelevant in this particular context of personal status and Shi'ism, where the persistent demand has been the precise, narrow and strict replication of juristic rules.

To be clear, this sort of narrow reconstruction of juristic rules into the stuff of modern legislation is not an easy task. Jurists write their rules in a fashion that is designed to enable the believer to live a good and righteous life, while legislation serves a different social purpose altogether. ${ }^{44}$ To attempt to make juristic rules into state legislation is thus to turn them into something they were never intended to be, and indeed almost by necessity radically restructures them. For example, much thought would need to be given to precisely what to do with a religious rule that "recommended" but did not "require" particular conduct on the part of a believer, or how to treat the substantial number of Shi'i rules that are described as "precautionary," meaning there is some doubt as to the permissibility of a given action and thus it is better to avoid it rather than risk falling into sin. ${ }^{45}$ Yet even if the project would be technically quite difficult, and indeed almost inevitably result in some level of distortion of the original rules themselves, the goal is nevertheless conceptually rather straightforward. It is to give life to the

43 Clark Lombardi, for example, describes various types of Islamic lawmaking in the modern Muslim world that are flexible and nuanced, and certainly do not merely replicate juristic rules of medieval origin. CLARK LOMBARDI, STATE LAW AS ISLAMIC LAW IN MODERN EGYPT: THE INCORPORATION OF THE SHARI'A INTO EGYPTIAN CONSTITUTIONAL LAW 78-100 (2006). Mohammed Fadel makes the argument that the classical Sunni Islamic state did broadly validate and legitimate lawmaking in a fashion that was independent of juristic rulemaking. Mohammad Fadel, A Tragedy of Politics or Apolitical Tragedy, 131 J. AM. ORIENTAL SOC. 109, 118-23 (2011). Asifa Quraishi has similarly taken the position that the traditional Islamic state operated on a principle of the separation of powers that gave it broad authority to develop its own law, even as the jurists separately derived rules from sacred text independent of state authority. Asifa Quraishi, Separation of Powers from the Perspective of Islamic Tradition, CONSTITUTIONALISM IN IsLAMIC COUNTRIES: BeTweEn UPHEAVAL AND ConTINUITY 63, 63-65 (Tilmann J. Röder \& Rainer Grote eds., 2012). Cf. W Ael Hallaq, The Impossible State 1-3, 10-14 (2013) (arguing that the modern state and its methods of rule-making are incompatible with the Islamic legal and political tradition).

44 Haider Ala Hamoudi, Understanding the Conflicts and Limitations of Iraq's Draft Personal Status Law, JURIST (Mar. 31, 2014), http:/jurist.org/forum/2014/03/haiderhamoudi-personal-status.php [hereinafter Understanding the Conflicts and Limitations of Iraq's Draft Personal Status Law].

$45 \quad I d$. For an example of a precautionary rule, see infra Section III.C concerning the ability of a child, upon reaching puberty, to disavow a marriage contracted for that child by a father or grandfather. 
religious rules in the form of state law, and at the very least not to deviate from them in order to serve some other political or ideological end. That this did not come to pass when legislation finally appeared is therefore a matter of some significance.

\section{B. The Emergence of the Ja'fari Personal Status Code of 2014}

On February 26, 2014, an image appeared across traditional and social media outlets throughout Iraq, quickly went viral, and led to an intense debate. ${ }^{46}$ The photograph was of the Minister of Justice at the time, Hassan Shammari, of the Shi'a Islamist Fadila party, stuffing a rolled-up document dozens of pages long into the gilded latticework that surrounded the tomb of Imam Ali ibn Abi Talib, the person to whom Prophet Mohammad was closest and his designated successor, according to the Shi'a. ${ }^{47}$ The document in question was the Ja'fari Personal Status Code, making its first public appearance, albeit in a manner that obscured its content. His back to the camera, Shammari gave the appearance of a devoted and determined man piously doing his duty to God and nation alike. The depositing of the law in the tomb of Ali could almost be seen, in this light, as the penultimate act of devotion, to be followed only by enactment of the law itself. The act signified that finally, after decades of delay, God's Law would reign in the land where the body of Muhammad's rightful successor lay buried.

A cynic, of course, might take a different view. The law Shammari took such pains to advertise in this manner hardly spoke to Iraq's pressing problems. If anything, it exacerbated them. ${ }^{48}$ Other problems soon came to light. The draft

46 The image remains on the internet in various locations. See, e.g., After His Attacks On The Religious Leadership, The Minister Of Justice Dedicates The Ja'fari Law At The Tomb of Imam Ali, http:/www.iraqpressagency.com/?p=45531\&lang=ar (last visited May 5, 2016). The intensity of the debate ultimately led to demonstrations of substantial numbers of women in Baghdad's streets, all of whom were wearing black to show opposition to the draft, for a period of four days around International Women's Day on March 8. Afraj Shawqi, Iraqi Women Wear Black on Women's Day in Opposition to the New Personal Status Law, AL-SHARQ AL-Awsat (Mar. 9, 2014), http://archive.aawsat.com/ details.asp? section $=4 \&$ article $=764106 \&$ issueno $=12885 \#$. VNJz8p3F-X4 .

47 MOOJAN MOMEN, AN INTRODUCTION TO SHI'I ISLAM: THE History AND DOCTRINES OF TWELVER SHI'ISM 14-15 (1987).

48 There is a broad consensus that one of Iraq's core problems at the time of the promulgation of the Ja'fari Personal Status Code, and one that helped lead to the rise of ISIS, was the high degree of sectarian tension that existed between the majority Shi'a population and the minority Sunni one. See, e.g., Kirk H. Sowell, Iraq's Second Sunni Insurgency, HUDSON INSTITUTE (Aug. 9, 2014), http:/www.hudson.org/research/10505iraq-s-second-sunni-insurgency. It is hard to see how the replacement of a national law with a series of laws that applied to individuals on the basis of their sect could possibly ameliorate that problem. 
was atrociously drafted as a technical matter. ${ }^{49}$ Among other things, internal contradictions and inconsistencies proliferated, ${ }^{50}$ certain phrasings seemed impossibly vague and incapable of being the subject of rational adjudication, ${ }^{51}$ and the draft often used different words to denote the same concept. ${ }^{52}$

49 See Understanding the Conflicts and Limitations of Iraq's Draft Personal Status Law, supra note 44.

so Hence, Article 87 describes "fraud" in procuring a marriage in the following manner:

Fraud is a characterization of a woman to a man in desire for marriage that she is free of a fault with knowledge of its presence, or silence about its appearance with knowledge of it, such that the man is deceived because of it and proceeds to marriage.

Draft Ja'fari Code, supra note 42 , at art. 87. Article 90 then indicates that "fraud is not realized simply by the silence of the woman or her guardian." This leaves one entirely confused as to whether silence over a "fault" (such as insanity, leprosy or other illness that permits a husband to invalidate a marriage) in fact constitutes fraud. This is but one of many examples. Id. at art. 90 .

${ }_{51}$ The definition of puberty for males is the attainment of fifteen years or earlier "if one of the bodily signs depended on by the Muslim jurists appears." Id. at art. 16(1). Grand Ayatollah Sistani describes this in more detail in his own juristic compendium:

1069: The signs of puberty . . for a male are one of three: First, the appearance of rough hair on the pubic region, irrespective of whether it is thick or thin. Second, the ejaculation of semen, whether it is ejaculated awake or in sleep, in sex or a dream or otherwise. Third, the completion of fifteen years. ...

2 Ali AL-Sistani, MinHaJ AL-SALIHEEN, 2: 1069 (2008) (hereinafter Sistani). These are the repetition of long-standing rules centuries old and must therefore be that to which the draft Code refers in its description of the "jurists of the Muslims." See, e.g., MuHAMMAD HASAN AL-NAJAFI, 26 JAWAHIR AL-KALAM FI SHARH SHARA'I AL-ISLAM 5-6 (Abbas alQuchani ed. 1981) (ca. 1841) (hereinafter JAWAHIR). The idea that Iraqi judges would adjudicate if a male had reached the legal age of adulthood for personal status purposes based on the appearance of pubic hair, or the onset of masturbation or wet dreams, is too ridiculous to contemplate.

Other highly ambiguous phrases appear as well, for example a clause entitling a person to will their property to a non-Muslim except if "the will is characterized as aid to the oppressors, or something similar, in which case it is not sound." Draft Ja'fari Code, supra note 42 , at art. 32 .

52 Articles 81 and 82 , for example, use two different terms to refer precisely to the same concept. Article 81 indicates that if a marriage is invalidated after "penetration," then a woman is entitled to the full dower for which she has contracted. $I d$. at art. 81 . Article 82 indicates that a marriage cannot be invalidated because of a problem with a wife (for example, her insanity) to the extent it occurs after the marriage contract is signed, irrespective of whether this is before "intercourse" (wata' in Arabic) or after it. Id. at art. 
Why then rush such a plainly unsatisfactory, almost amateurish, draft in the early part of 2014 to satisfy a demand that had stood unfulfilled for decades? Why not take more time to produce a more careful and technically satisfactory product? The reason is obvious, and common enough in any contemporary democratic state. National elections were only weeks away when Shammari introduced the draft Code. ${ }^{53}$ Shammari belonged to one Shi'i Islamist party, the Fadhila. ${ }^{54}$ He was therefore obviously soliciting votes among the Shi'a faithful. The aim was not to draw them away from voting for a Sunni dominated list or even a multisect one, since there was no realistic danger of either of these happening in large numbers. Rather the aim was to ensure that they supported Fadhila over the other conservative Shi'i Islamist lists, among them the Sadrists, the Islamic Supreme Council of Iraq (formerly known as the Supreme Council for the Islamic Revolution in Iraq), and the Da'wa party, since renamed the Coalition for the State of Law and under the leadership of then Prime Minister Nouri alMaliki. ${ }^{55}$ The draft was thus a play for the votes of a very large Shi'i conservative base, upon whose support the premiership of the state hinged. ${ }^{56}$ In light of these facts, the entire method of unveiling the law at the tomb of Shi'i Islam's most revered figure, after the Prophet Muhammad himself, appeared more like a meretricious publicity stunt rather than an act of devotion.

Nevertheless, despite the rather transparent political motivations for the creation of the draft, it became nearly impossible for the other Islamist parties to resist joining in support of it. Whatever misgivings they might have had about a horribly drafted law and the vulgar manner in which it was unveiled paled in comparison to the fear that the socially conservative Shi'a voters for whose support they were competing might view them as somehow "secular" or at least insufficiently committed to the substance of Shi'i Islam. Given these political pressures, the cabinet endorsed the draft and sent it to the legislature for a vote in late February. ${ }^{57}$

Events, however, soon derailed the project. First, there was the fact that one of the four Grand Ayatollahs of Najaf, Bashir al-Najafi, denounced the draft

82. This is but one of many places where the two terms seem to be used almost haphazardly.

53 National elections were held in Iraq at the end of April of 2014. See Sowell, supra note 48 .

54 Ali A. Allawi, The Occupation of Iraq: Winning the War, Losing the PEACE 439 (2007) (describing Fadhila as one of the six major Shi'i Islamist parties in Iraq).

55 See id.

56 These different Shi'i Islamist parties find themselves vying with each other for the support of the same Shi'i devout constituency quite frequently. For an example of similar competition in 2009, see HAIDER Ala HAMOUDI, NEGOTIATING In CIVIL Conflict: CONSTITUTIONAL CONSTRUCTION AND IMPERFECT BARGAINING IN IRAQ 177-79 (2014).

57 Haifa Zangana, Ja'fari law takes the Iraqi government's violation of women's rights to a new level, THE GUARDIAN (Mar. 14, 2014), http:/www.theguardian.com/ commentisfree $/ 2014 / \mathrm{mar} / 14 /$ jafari-law-iraqi-violation-women-rights-marital-rape. 
Code for its many flaws a day after the Cabinet had approved it. ${ }^{58}$ Soon thereafter, ISIS took control of a number of Iraqi cities as the Iraqi army collapsed and fled. ${ }^{59}$ The nation plunged ever deeper into political crisis, ultimately leading to the national legislature's selection of a new prime minister. ${ }^{60}$ Iraqis soon forgot the Ja'fari Personal Status Code.

It is important, however, not to disregard the importance of the draft Code. For one thing, its failure in one term hardly means something like it will never find its way into law. After all, the bill was presented for a legislative vote after one Shi'i Islamist party wrote it in some haste to demonstrate its religiosity, and its closest competitors felt obligated to endorse it. Given this, it is not inconceivable by any means that one party or another takes similar steps in the future, and in fact forces a positive vote on the legislation, in particular if future drafters amend parts of it in a manner that meet with Najaf's approval.

But more relevant for the purposes of this Article, even without its enactment, is that the atrocious state of the draft reveals more clearly the stark tensions between the two competing forces that led to its creation. The first of these forces was the decades-long desire for the personal status law to reflect Shi' $i$ juristic rules for the Shi'i population. The second was the practical, ideological predispositions of the socially conservative Shi'i voters whom the competing parties were courting in promulgating (in the case of Fadhila) and endorsing (in the case of the other Shi'i Islamist parties) the draft legislation.

Seen in this light, the hasty and awkward draft Code is quite worthy of study. If there is to be a second attempt at such a Code, then it will likely prove to be more carefully prepared. Having had the experience of this initial draft Code, the authors of a new draft will probably recognize the tensions between religious rules and conservative expectations and manage them with more subtlety, thereby potentially disguising the important distinctions between the two. With the haste, and the imprecision, the mask fell off. The awkward draft makes absolutely clear that what the drafters are endorsing is not the realization of any sort of juristic rulemaking, but rather a socially conservative vision of society endorsed by tribes and rural notables with only casual resemblance to the version of Islam promulgated by the jurists. The balance of the Article demonstrates how this is so.

58 See Understanding the Conflicts and Limitations of Iraq's Draft Personal Status Law, supra note 44 (indicating that Najafi described the Code in rather harsh terms as "rife with flights of fancy in legal and juristic formulations that render it impossible that a jurist would find it acceptable").

$59 \quad$ Iraq at a Crossroads: Options for U.S. Policy: Hearing before the United States Senate Committee on Foreign Relations, 113th Congress (2014) (statement of Brett McGurk, Deputy Assistant Secretary of State for Iraq and Iran).

60 See Taylor, supra note 17 (respecting the election of al-Abadi as Prime Minister). 


\section{DISTORTING THE DOCTRINE AND MANAGING THE DIVIDE: MARRIAGE AND THE DRAFT JA'FARI CODE}

\section{$\underline{\text { A. Marriage in Islamic Law }}$}

Of all of the traditionalist rules contained within the broad rubric of the shari'a, few of them present as many problems in modernity as those concerning marriage. The discrepancy with modern expectations, liberal and conservative, begins with the very purpose of marriage. Within both Shi'i and Sunni traditions, this purpose was to render sex licit, and the primary reason to do that is to facilitate sexual enjoyment. ${ }^{61}$

Thus, focusing for the purposes of this Article on the rules of the Shi'i tradition (though noting that the Sunni rules are not markedly different), ${ }^{62}$ a man's primary obligations are to pay his wife in two forms. The first is a dower agreed upon between the parties at the time that the contract for marriage is concluded, which can be virtually anything of value. ${ }^{63}$ If they fail to make an agreement on the dower to be given to the wife in exchange for the marriage, the contract is valid, and a "dower of equivalence" is imposed. This is calculated by comparing the bride to a woman of similar station and similar characteristics in matters such as youth, virginity, intelligence, morals, elegance, and honor. ${ }^{64}$

According to these traditional rules, the payment terms are tied rather closely to sexual intercourse. Specifically, a husband need only pay half of the dower if he divorces his wife before he has sex with her. ${ }^{65}$ Should he fail to pay the part of the dower due when the contract is signed, ${ }^{66}$ the woman may refuse sexual intercourse until he does. ${ }^{67}$ The connection of the dower to sexual intercourse is even clearer in the circumstances where dower is due in the absence of a marriage. Hence, if a man rapes a virgin, or otherwise causes the tearing of her hymen without her consent, he must pay the dower of equivalence for a virgin

61 See TUCKER, supra note 4 at 41.

A good review of the traditional Sunni juristic rules comparable to those discussed in the main text with respect to Shi'ism is contained in id. at 41-59. Because the focus of the Article is on the Ja'fari draft Personal Status Code, which purports to be the realization of Shi'i rules applied exclusively to Iraq's Shi'a, I do not discuss Sunni conceptions of marriage in very much depth.

See, e.g., SISTANI, supra note 51, 3: $\mid 287$; JAWAHIR, supra note 51, 31:3-4 (relating a story wherein the Prophet Muhammad suggested a dower involving an indigent husband teaching his wife a verse of the Qur'an).

64 SISTANI, supra note 51, 3: ๆף294-95; JAWAHIR, supra note 51, 31:49, 52.

65 SISTANI, supra note 51, 3: $\lceil 306$; JAWAHIR, supra note 51, 31:80.

66 The dower can be paid in full at the time of contract, or some or all of it can be deferred to a later date. SISTANI, supra note 51, 3: ๆ302.

67 JAWAHIR, supra note 51, 31:41. 
as damages. ${ }^{68}$ Earlier jurists create an entire category referred to as the "losing of the vulva" where dower would be due from a third party if that third party made it impossible for a husband to have sex with his wife again. ${ }^{69}$ Examples include a circumstance where a father had sex with his son's wife, thereby preventing the son under long standing shari'a rules from having sex with her again. ${ }^{70}$

The other significant financial obligation of the husband to his wife is to provide for his wife in the form of shelter, clothing, and food, at a standard that a woman of her station would reasonably expect. ${ }^{71}$ Sistani describes ancillary obligations as well. For example, a man cannot "oppress" his wife, or even verbally assault her, and if he intends to leave her, he should divorce her rather than leave her "hanging," neither married nor divorced. ${ }^{72}$

In return, the jurists encapsulate a woman's primary obligation through the frequent use of a single word - tamkeen, roughly translated as "enablement." 73 Specifically, a wife must "enable" her husband to enjoy her body at a time and place of his choosing, with very limited exceptions. ${ }^{74}$ Her ancillary obligation is

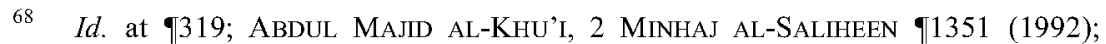
MUHAMMAD SAEED AL-HAKIM, 3 MINHAJ AL-SALIHEEN 161, http:/alhakeem.com/arabic/ pages/book.php?bcc=1485\&itg=1\&bi=56\&s=ct (last visited Mar. 26, 2016).

69 JAWAHIR, supra note $51,31: 2$.

70 Id.

71 KHU'I, supra note 68, at 287; JAWAHIR, supra note 51, 31:330

72 SISTANI, supra note 51, 3: $\mid 240$. Other jurists do not categorize these specifically as a wife's rights in marriage, though analogous provisions appear. For example, earlier texts contain passages that enable a wife to petition a judge under circumstances where a husband has left her but not divorced her for permission to obtain financial support from her husband's resources. JAWAHIR, supra note 51, 31:353-54. This is not, however, described as a wife's right, but rather a means for a wife to ensure that her husband fulfills his obligation. Thus, this rule appears within a broader section outlining the parallel obligations of support on the part of the husband, and enablement on the part of the wife. Sistani's re-categorization of this as a wife's "right" recalls Robert Cover's invaluable insight that Western secular society often adopts the discourse of rights where religious law (and in his specific instance, Jewish law) prefers the language of obligations. Robert M. Cover, A Jewish Jurisprudence of the Social Order, 5 J. L. \& REL. 65, 65 (1987). I might only add that even the most traditionalist of contemporary authorities in Shi'i Islam have been influenced enough by post enlightenment secular trends as to recast religious law in the discourse of rights as well.

73 JAWAHIR, supra note 51, 31:303

$74 \quad I d$. at 303 ("when she enables him ... such that she assigns neither a place nor a time for which his enjoyment is permitted for them, then he must support her, and if she does not, then he has no obligation."); SISTANI, supra note $51, \$ 337$ ("the right of a husband against his wife is that she enable him to near her, and otherwise [enable him] for the enjoyments established for him as the [marriage] contract requires, at any time he wishes, and that she does not prevent him except for a legitimate reason . . . .") As Sistani's text indicates, a woman can deny her husband sex in certain, limited circumstances. For example, she has no obligation to "enable" him when she is sick. JAWAHIR, supra note 51, at 31:312. Similarly, in keeping with the Prophet Muhamad's statement that "there is no obedience to a creature that involves disobedience to the Creator," a woman's performance 
not to leave the marital home without his permission, as this plainly interferes with a husband's right to enjoy his wife sexually whenever he wishes. ${ }^{75}$ A wife's failure to uphold her obligations entitles her husband to deny her maintenance because of her "rebelliousness.", In addition to denying her support, a husband may discipline a rebellious wife by verbally chastising her. ${ }^{77}$ If that fails, he may leave her bedside. ${ }^{78}$ If this does not work to prevent her rebelliousness, then he may beat her to the minimum extent necessary to achieve her obedience, with the purpose of discipline and not revenge, so long as the beating is not so severe as to cause bruising or bleeding. ${ }^{79}$ If the beating exceeds these bounds, then he must pay damages for the injury incurred. ${ }^{80}$

Historic juristic texts, Sunni and Shi'i, had little trouble explaining much of this through an explicit comparison to sale. ${ }^{81}$ To quote one of the most influential Shi'i juristic compendia:

As is explained in the book of sale, the essence [of sale] is as a name for the transfer of possession, not for the contract and not for the process of transferring it. We said that what is uniform in all of its uses is the actual oral expression in the contract offer. . . So what is desired from "I sell" as an offer is not "I contracted" nor even the delivery, but the transfer of possession. This all applies in the oral expression "I marry" as an offer, as the desire in the contract would be debauchery, and sex, so there is nothing left but the transfer of the possession of the vulva, the exercise of power over it, and the settled establishment of that power, and that is what is desired in a marriage, as with sale, conciliation, lease and other [contracts]. ${ }^{82}$

of obligatory fasting, prayer or pilgrimage frees her of her enablement obligation while performing those obligations. The same is not true, however, for religious observances that are not obligatory, but merely recommended or permitted. JAWAHIR, supra note 51, $31: 314$.

75 SISTANI, supra note $51, \boldsymbol{q 3 3 7}$; JAWAHIR, supra note 51, 31:314.

76 JAWAHIR, supra note 51,31:314.

77 SistaNI, supra note $51, \uparrow 353$.

78 Id.

$79 I d$.

80 Id. The rules as cited in the main text concerning wife beating are those of Sistani. Other jurists do not delve into this level of detail respecting the limitations of a husband's physical discipline. Khu'i, for example, only indicates that in the case of rebelliousness, if admonishment and leaving the bedside do not succeed, then a husband "may strike his wife without causing bruising or the breaking of bones." KHU'I, supra note 68, 2: $₫ 1365$.

81 See Ali, supra note 6, at 6.

82 JAWAHIR, supra note 51, 29:7 (emphasis added). 
In other words, what constitutes a legitimate sale is not the contract itself, or the process of delivering the item sold, but in fact the actual transfer of possession. Similarly, an offer for marriage does not constitute a marriage, nor does the process of conveying a desire for sex, as this is merely debauchery. Rather, it is the transfer of possession of the wife's vulva, and the exercise by the husband of his power over the vulva, which renders it a legitimate contract for marriage. Hence the woman is the seller, and she offers her body, and the man is the purchaser, who concludes the contract when he takes possession of it.

Then, the balance of the rules set forth above fall into place. Naturally, a dower must be due to a raped virgin, as that which she had the right to sell has been taken. ${ }^{83}$ Similarly, it follows from this that a woman cannot deny a man sexual intercourse at a time and place of his choosing. Because he has purchased her genitalia through marriage, she can no more deny him access to his purchase than one who sells a horse can deny its new owner use of it.

Beyond a doubt, any devout, Muslim liberal would find these traditionalist rules offensive in the extreme and moreover regard them as the result of a patriarchal reading of sacred text rather than some sort of necessary interpretation of it. ${ }^{84}$ However, even Muslim social conservatives are troubled by some of the more obvious commercial implications. Their imagination of marriage includes a wife's sexual obedience, but it also involves almost Victorian ideals of child rearing and homemaking as well. ${ }^{85}$ This is certainly not part of the marital bargain in the juristic texts. ${ }^{86}$ That is to say nothing of love and intimacy, which is very much part of the Muslim conception of marriage in our times, among liberals and conservatives alike, but not contemplated by the juristic rules. The Qur'anic verse most commonly cited by imams and clerics in modern Muslim weddings comes from the Chapter of Rome, referring to the mercy and tenderness that God puts between spouses. ${ }^{87}$ The juristic references to sale of a vulva hardly seem consonant with this part of Islam's Holy Book.

Conservative discomfort might well explain why contemporary jurists, while not altering the substantive rules, have also not attempted to explain their origins or justify them through sale analogies in their compendia. A fascinating

83 See supra note 68 and accompanying text (concerning the obligation of a rapist to pay a dower of equivalence).

84 See, e.g., WADUD, supra note 6, at 2-3 (indicating that historic interpretations of the Qur'an were almost always undertaken by men and that this has affected contemporary understandings of it).

85 ALI, supra note 6, at 6.

86 Sistani, for example, makes clear that a husband cannot obligate his wife to perform household chores, nor is she derelict in her marital obligations for failing to do them, even if her voluntary performance of them is religiously recommended. SISTANI, supra note 51, 3: 9340 .

87 Qur'an 30:21 (Yusuf Ali trans. 1934) ("And among His Signs is this, that He created for you mates from among yourselves, that ye may dwell in tranquillity with them, and He has put love and mercy between your (hearts): verily in that are Signs for those who reflect."). 
example lies in the explanation respecting a wife's right to deny her husband sex until she receives her dower. The Jawahir, relying upon the sale analogy common in Shi'i texts before the twentieth century, explains this as follows:

She may refuse sex and the surrendering of her body until she receives her dower by agreement, and the same is true for lifting her veil and other matters. This is because the marriage with the dower is compensation for [those actions]. She is not alone using these appropriate means. Every party to be compensated may refuse to surrender until they receive the compensation. Based on the report of Zur'a bin Sama'a, "I asked him about a man who married a maiden and enjoyed her then she rendered him free of his dower. May he have intercourse with her before he gives her anything? He said, 'Yes. If she rendered him free, then she has taken the dower from him." But for embarrassment, difficulty, harm, or oppression, she should not deny him, because the vulva is compensation by consensus, and the marriage is compensation first. Based on plentiful texts [i.e. original source material], what the husband gives her enables him to have sex with her, and makes her vagina permissible to him. ${ }^{88}$

Hence, the Jawahir tells us a woman who has not received her dower can of course deny sex, just like any seller who has not received his advance payment for the item he is selling may refuse to surrender the item sold. Once payment is given, however, the woman must tender her body because it is then under his possession. Consequently, she cannot after he has paid deny him out of embarrassment, difficulty, or even harm.

In contrast to the Jawahir, Sistani's analogous rule appears in far more cursory form as follows:

If a dower is immediate, then the wife may refuse enablement before she takes it, irrespective of whether the husband was capable of delivering it or not. But if she enables him of her, then she cannot deny him after that until she receives it. ${ }^{89}$

The rule is largely similar, entitling a woman to deny sex before she receives her dower, but not entitling her to do so once she has already consented to sex. Yet

88 JAWAHIR, supra note $51,31: 41$.

89 SISTANI, supra note 51, 1306 . There is a slight yet potentially significant difference in that the Jawahir suggests that the dower is constructively paid by a woman who consents to sex, while Sistani does not intimate this, indicating only that the woman may no longer refuse sex pending receipt of the dower. In the interests of space, I do not address this distinction herein. 
the bases for the rule have disappeared, thereby allowing modern clerics to describe the dower more as a gift that a husband must give to his wife, the Islamic equivalent of the contemporary diamond ring. ${ }^{90}$ Such clerics also properly describe the dower as protection against an arbitrary divorce by a husband, given that the husband must tender any dower not paid during the marriage no later than death or divoree. ${ }^{91}$ In other words, a husband with a large outstanding dower might hesitate before pronouncing divorce because he would then become liable for the full amount of the dower balance immediately.

Yet even if these descriptions are somewhat accurate, they are incomplete. They do not explain a fair number of the rules described above. It would be odd to demand the return of half of the value of a diamond ring if there had been no sex prior to the dissolution of the marriage. It would be odder still to obligate the rapist of a virgin to give his victim a gift, and the idea of insurance against divorce in such an instance is entirely incoherent.

In any event, given the helpful mask on doctrinal origins of dower provided by Sistani, and supported by the discourse of contemporary lower level clerics and imams, the fiction respecting the purposes of marriage and its attendant rules within the historic tradition becomes plausible enough to render the matter more appealing to Muslim social conservatives. As such, it is unsurprising for the most part that the draft Code repeats the juristic rules in large part on the matters described in this section. Articles 101-02 of the draft Code read as follows:

Article 101: The right of the husband over his wife are two matters:

(1) That he she enables him to near her for the enjoyments established for him in accordance with the contract at any time that he wishes, that she does not prevent him except for a legitimate reason, and that she does not take any action that denies his right of enjoyment; and

(2) That she does not leave the marital home except with his permission.

90 See, e.g., Sayyid Moustafa al-Qazwini, Divorce, Divorce and Mahr Proprietorship, in AL-IsLAM.org, AHLUl BAYT DigITAL ISLAMIC LIBRARY Project, http:// www.al-islam.org/a-new-perspective-women-islam-fatma-saleh-moustafa-al-qazwini/ chapter-3-divorce-divorce-and-mahr\#divorce-and-mahr ("The [dower] is a gift to the wife irrespective whether of the marriage continues or later dissolves. If the husband has not paid the [dower] in full, then he will still be held liable for the remaining balance, despite the reasons for divorce."). Sayyid Qazwini is one of the most well-known and widely followed Shi'i clerics in the United States. He is the founding Imam of the Islamic Educational Center of Orange County, California. Id. at About the Authors. 
Article 102: The right of the wife over the husband is limited to the following:

(1) That he spends on her for her good, her shelter and all that she needs based on her station;

(2) That he does not hurt or oppress her, nor quarrel with her without a legitimate reason;

(3) That he does not abstain from her entirely, and render her hanging, neither married nor divoreed; and

(4) That he does not leave from near her for more than four months, and if the wife cannot be patient for four months, then the husband must come nearer before the four months, or divorce her and free her path. ${ }^{92}$

Similarly, the rules on dower indicate that a woman has the right to the dower set by the contract. ${ }^{93}$ If no dower is named, then a dower of equivalence is imposed. ${ }^{94}$ A dower of equivalence is also imposed on rapists, though the draft Code seems not to distinguish between the rape of virgins and non-virgins in the manner that the juristic texts do. ${ }^{95}$

It is precisely rules such as these that led to the outcry against the draft law by liberal and secular forces. ${ }^{96}$ Yet that did not matter at all to the drafters of the Ja'fari Code, who could count on the opposition of those secular and liberal forces to their law no matter how it was framed. What was important to the drafters was that the rules align well with the expectations and predispositions of the conservatives whom they were courting. This they certainly do. If most of the bedrock supporters of a draft Ja'fari Code also allowed for such elements as companionship and intimacy to play a role in marriage as well, they would not necessarily insist on the recognition of such matters in legislation. So long as the references to sale remained implicit, and marriage could be plausibly described as much greater than a barter of sexual access, the devout could be satisfied by the traditional formulations. In the end, mirroring Sistani's rules worked to satisfy the constituencies who might support the bill. This proved not to be the case with other important aspects of marriage, however, as further described below.

92 Draft Ja'fari Code, supra note 42 , at arts. 101-02.

$93 \quad$ Id. at art. 91.

$94 \quad$ Id. at art. 92.

$95 \quad I d$. at art. 91. This might very well be another area where the drafters changed the juristic rules in order to meet Muslim social conservative expectations. I do not discuss it, however, because it is possible that this is merely the result of shoddy work and inattention to detail. It is not obvious that social conservatives would necessarily have strongly held views on the specific rules regarding rape and dower. This is not true of the other matters discussed in the balance of the Article, where the decision to derogate from the rules is perfectly obvious.

96 See, e.g., Shawqi, supra note 46 (describing days-long demonstrations against the law); Zangana, supra note 57 (offering extensive criticisms of the law). 


\section{B. The Temporary Marriage}

A modern problem concerning the historic analogy between marriage and sale arises solely within Shi'ism because of a curious additional form of marriage. This is the temporary, or "pleasure," marriage. ${ }^{97}$ Where Shi'i jurists historically would analogize marriage to sale, as described in the previous section, they analogize the temporary marriage to lease, with the dower being the necessary compensation for the lease. ${ }^{98}$ The Jawahir explains the distinction as follows:

The dower is a special condition of the temporary marriage, and the contract is void without it, without disagreement and indeed by consensus. It is the basis [for it] based on the statement [of Shi'a Islam's Sixth Imam] 'there is no temporary marriage, without two matters. A set time, and a set rent.' . . . And in other report, 'the women are leased,' as with the statement [of the Fifth Imam] 'she is leased.' From this the difference is known between the permanent, with whom one wishes offspring and the like, and the temporary, from whom one desires usufruct and pleasure and the like, as a result of which it resembles a lease, and thus the dower is compensation for the lease and a condition for its validity. ${ }^{99}$

The wife must, moreover, "enable" her husband precisely as in an ordinary marriage in exchange for the dower, and partial enablement leads to a reduction in the dower, as described below.

Thus, it is obligatory to pay the dower required in the contract . . . as the dower earned, but it is settled upon intercourse and her fulfillment of enablement during the period [of the marriage]. . . [A man said] to the Sixth Imam, "I married a woman for a month, and she wants the entire dower, but I fear she will stay away from me. He said 'it is not permitted to hoard that which she has power over, but if she does stay away from you, then take back [the dower] in the amount that she has stayed away." 100

Unsurprisingly, as with permanent marriage, the explicit references to leasing the genitalia of women have disappeared from the discourse of modern jurists. Hence, Sistani summarizes the same rules set forth above without that analogy:

97 JAWAHIR, supra note 51, 30:139-49 (describing the differences between the Sunni and Shi' $i$ positions on the temporary marriage at some length in a polemical fashion).

$98 \quad I d$. at $30: 162$.

$99 \quad I d$.

$100 \quad I d$. at 30:164. 
Marriage is a contract between a man and a woman, pursuant to which each of them is permissible to the other. It is of two types: permanent and temporary. The permanent contract is one where the duration of the marriage is not set, and the wife is called she who is permanent. The non-permanent contract is one where a duration is set, as an hour, a day, a year, or more or less, and the wife is called she who is enjoyed, or temporary.

It is a condition of the temporary marriage to name the dower. If there is a contract without a named dower, intentionally or out of ignorance or forgetfulness, it is invalid. ...

She who is enjoyed owns the entire dower of the contract, but it is settled entirely on condition that she does not breach her enablement set forth for her as a requirement in the contract. If she breaches for part of the period, then her husband may take from the dower in proportion [of the failure to enable]. . . ${ }^{101}$

As the above passage makes clear, try as they might, jurists cannot disguise the inherently commercial nature of the transaction as they can in the case of permanent marriage. A modern traditionalist cleric might be able to describe the dower as a "gift" in a permanent marriage, and sustain a fiction that indeed it is a gift rather than compensation for sex despite rules which strongly suggest otherwise, and despite historic texts which very much say otherwise. ${ }^{102}$ The same principle is simply not credible in the case of a marriage that can last as little as an hour, or less. Other rules, such as the fact that a husband in a temporary marriage owes no support to his wife, even if she becomes pregnant by him, only help to fortify the conclusion that what is involved in a temporary marriage is neither intimacy nor child rearing. ${ }^{103}$ It is quite obviously the sale of sex.

Given all of this, modern developments respecting the temporary marriage have usually involved Sunni polemicism and Shi'i apologetics. As concerns Sunni polemics, it is easy for modern Sunni clerics to disparage Shi'ism for permitting temporary marriages once Sunnism had successfully disguised the commercial nature of the permanent Islamic marriage contract as Sunni classical jurists explicated it. Hence, for example, the leading commentator on Iraq's Personal Status Code, the Sunni Ahmed al-Kubaisi, indicates that a condition of the marriage is that it be permanent, explaining as follows:

Marriages [that are for a limited duration] contradict the religious purpose of marriage, which is a settled life, the

$101 \quad I d$. at $\$ \uparrow 30,233,237$. Exceptions lie where intercourse would not be permissible, and in particular during the wife's menstrual period. JAWAHIR, supra note 51, at $\uparrow 237$.

102 See supra notes 81-82 and accompanying text.

103 JAWAHIR, supra note $51, \uparrow 256$. 
permanence of intimacy, the establishment of family, the raising of children, the assumption of responsibility, the realization of social solidarity, and the organization of civilization which results in the building of the self and the continuation of life. . .

[The temporary marriage] is deemed corrupt in Iraqi courts, and it has no consequences of a valid marriage. ${ }^{104}$

As a traditionalist who does not hesitate to express his outrage at "innovations" that derogate from the traditional juristic rules, such as legal restrictions on polygamy, ${ }^{105}$ Kubaisi is surely aware of his intellectual dishonesty in describing the "religious purpose" of marriage in classical texts as relating to intimacy, settling down, and assuming family duties and responsibilities. Surely, given his insistence that other traditional juristic rules be followed without reform, the more honest approach would be to describe the Islamic juristic rules for permanent marriage as what they are - the sale of a vulva for support and a dower. ${ }^{106}$ Yet as we have seen, the re-characterization of the purposes of permanent marriage (without simultaneously changing its rules) has been dramatically successful in the modern era. ${ }^{107}$ Indeed, it has been so successful that a criticism that medieval Sunni scholars could not have possibly had about the temporary marriage - that it is commercial in nature and that it is centered on sex-is one that a Sunni cleric can credibly raise as the reason to ban temporary marriages.

For their part, Shi'i Iraqis are aware of the juristic permissibility of the temporary marriage, and yet are uncomfortable with it. It is a form of marriage that is not engaged in with any regularity, and regarded with extreme hostility as a

104 Ahmed al-Kubaisi, 1 Personal Status in the FIQH, The CoURTs and the LAw 70-71 (2d ed. 2007). As an additional example of these sorts of polemics on the Internet, see A. Muhammad, Does the Quran Permit Temporary (Mut'ah) Marriages, True IsLAM, http:/www.quran-islam.org/articles/part_4/temporary_marriages_(P1437).html (last visited Mar. 27, 2016):

God would never advocate sin, not plain sin nor disguised sin. Anyone who writes a temporary marriage certificate for the sake of sexual activities is trying to disguise his $\sin$. In fact he would not be any different from someone who hires a prostitute for a day or a week for sexual services. The only difference is that the first man conjured up a piece of paper and adds the title "marriage" to it! But the act, in purpose and execution, is the same.

105 KUBAISI, supra note 104 , at 110-15. Kubaisi goes so far as to describe some of the efforts to ban polygamy as part of a plot to limit the number of Muslims in the world. Id. at 111 .

106 See Asifa Quraishi-Landes, A Meditation on Mahr, Modernity and Muslim Marriage Contract Law, in FEMINISM, LAW AND RELIGION 178 (Marie A. Failinger, Elizabeth R. Schiltz and Susan J. Stabile eds. 2013); see also ALI, supra note 6, at 6.

107 See ALI, supra note 6, at 6. 
practical matter. ${ }^{108}$ The idea that a virgin Iraqi woman of any age would actually be able to lease her genitalia for an hour to a man would horrify Iraqi conservative forees, from urban elite to tribal elder. Tribal leaders have told me quite directly that they regard this as fornication meriting death, waving off in indignation and embarrassment any questions respecting the legality of the pleasure marriage. ${ }^{109}$

This creates a problem for the drafters of the Ja'fari Personal Status Code. To draft a code without any reference to the pleasure marriage would plainly disregard a core element of Shi'i marriage doctrine in deference to the Sunni prohibitions on the practice. This is precisely the type of legislative selectivity that the Code is supposed to eradicate, as part of a long-standing Shi' $i$ demand to live by self-defined rules of personal status. ${ }^{110}$ Yet to keep it would legalize and legitimize a practice which deeply embarrasses most Shi'a, and which Sunnis would use as part of a broader polemical assault on Shi'ism.

The solution by and large was to dispense with pleasure marriage entirely in the draft Ja'fari Personal Status Code. It is simply too far removed from the contemporary Iraqi experience and too problematic on normative grounds that exist independently of juristic texts to be able to receive due recognition in a draft law. Hence, the draft Code's rules of marriage nowhere suggest that marriage might be temporary and nowhere include reference to how durations might be set during contracting. Perhaps even more importantly, the husband's obligation to support his wife during a marriage is set forth in unconditional terms in Article 102 , thereby explicitly derogating from the Shi'i rule which has no such support obligation in a temporary marriage. ${ }^{111}$ The same is true for other areas where the rules for temporary marriage differ from those of permanent marriage. In each and every case, the draft Code sets forth rules for permanent marriage and does not mention at all the different rules for the temporary marriage established in the juristic texts. ${ }^{112}$ In other words, the drafters adopted the Sunni position on

108 KUBAISI, supra note 104, at $7 \mathrm{n} .2$ ("From a practical standpoint, [the Shi'a], and especially those we have in Iraq, do not engage in [temporary marriage] and deem it among the contemptible forms of marriage.").

109 In the spring of 2013, I spent a great deal of time in Iraq interviewing tribal leaders and observing tribal resolution processes with two professors from Basra University School of Law, Wasfi al-Sharaa and Aqeel al-Dahan. Most of my time was spent among Shi'i tribes located in Baghdad, particularly Sadr City, though inevitably members of those tribes had relocated from elsewhere. The fruit of our research will appear in Haider Ala Hamoudi, Wasfi Alsharaa \& Aqeel al-Dahan, The Resolution of Disputes in State and Tribal Law in the South of Iraq: Toward a Cooperative Model of Pluralism, in Negotiating State and Nonstate Law: The Challenges of Global and Local Legal PluRALISM 215 (Michael A. Helfand ed., 2015).

110 See supra Section I.A (describing formal reason for Code being to permit the Shi' a to live by their own rules of sect).

11 Draft Ja'fari Code, supra note 42, at art. 102 (1) (describing support as the right of a wife against her husband).

112 For example, the draft Code sets forth specific rules respecting when a man may pronounce a unilateral divorce against his wife. Id. at arts. 135-36. It does not mention the 
temporary marriage, a remarkable result for a Code whose very purpose was to enable the Shi' a not to have to abide by Sunni rules imposed on them. ${ }^{113}$

There is one curious exception to this, however. In one, and only one, place in the draft Code, there is an implicit reference to the temporary marriage being permissible. This lies in Article 63, which reflects the long-standing Shi'i juristic rule that a Muslim may not marry a non-Muslim. ${ }^{114}$ This is in contrast to the Sunni rules (and the existing Personal Status Code, which adopts Sunni rules on this point), which permit a Muslim man to marry a non-Muslim woman, though not the reverse, so long as she is what is regarded in Islamic discourse as a "Person of the Book," defined generally as the follower of an Abrahamic religion. ${ }^{115}$

While Shi'ism does not permit marriages outside of Islam generally, it does provide an exception for Muslim men engaged in temporary, rather than permanent, marriage. ${ }^{116}$ Interestingly, Article 63 recognizes this distinction, indicating that, "a marriage of a Muslim woman to a non-Muslim is not sound as an absolute matter, and the permanent marriage of a Muslim man to a woman other than a Muslim, or an apostate from the Islamic religion, is not sound as an absolute matter." 117 The reference to "permanent" breaks the Code's general approach of disregarding the temporary marriage, given that it suggests that there is a type of nonpermanent marriage pursuant to which a Muslim man might marry a non-Muslim woman, but not the reverse.

The reason for this is again an attempt to placate potentially socially conservative Shi'a who might be expected to support the bill. The phenomenon of intermarriage between Iraqi men and foreign women was widespread enough to result in the constitution specifically granting Iraqi citizenship rights to anyone born to an Iraqi parent, even if the other parent was foreign, without objection from Shi'a Islamist forces. ${ }^{118}$ This is unsurprising because among urban elites in

prohibition against divorce in temporary marriage, despite this being a clear rule concerning the temporary marriage. See SIsTANI, supra note 51, 3: q252. Similarly, the waiting period after which a divorced woman may generally remarry is set in the Code as three menstrual cycles. Draft Ja'fari Code, supra note 42, at art. 155(2)(a). This is the rule for the permanent marriage, but a temporary wife generally needs to wait only two menstrual cycles. SisTANI, supra note 51, 3: $\mid 259$.

113 See supra Section I.A (describing formal reason for Code being to permit the Shi' a to live by their own rules of sect).

114 Draft Ja'fari Code, supra note 42, at art. 63.

115 Iraq Personal Status Code, supra note 27, at art. 17; KUBAISI, supra note 104, at 109-10.

116 SISTANI, supra note 51, 3: ๆ232; JAWAHIR, supra note 51, 30:155.

117 Draft Ja'fari Code, supra note 42, at art. 63 (emphasis added).

118 As has been reported, the constitutional provision did change the existing law and did prove controversial because it granted citizenship to children of Iraqi women and nonIraqi men. Sara Burhan Abdullah, Citizenship and Women's Rights under the Iraq Constitution, JURIST (Jan. 30, 2010), http:/jurist.org/dateline/2010/01/iraq-citizenship-andwomens-rights.php. However, there was broad agreement among all parties_-Islamists and 
particular, a good number of Shi'is have over the past several decades married foreigners, including non-Muslims. ${ }^{119}$ To declare all such marriages void, and those engaged in it as fornicators, would be quite problematic not only for the person engaging in the practice, but also for those who work and interact in the same social circles. The law would delegitimize significant numbers of Iraqi marriages, and prohibit a practice that is likely to continue.

Thus, the reference to permanent marriage in Article 63 was not so much to legitimize the pleasure marriage as it was to deal with another problem in which juristic rule does not conform to modern conservative social expectation, and this relates to the broad acceptability of interreligious marriage among Muslim men and non-Muslim women. The only real manner in which to permit such marriages while still complying with religious dictate was to hint at their permissibility through a separate vehicle, the pleasure marriage, which carries its own, set of problems so severe that it is not referenced anywhere else in the Code. The result is something of an obvious incoherence, and hardly an accurate reflection of juristic rules.

\title{
C. The Child Marriage
}

Curiously, the drafters adopted a very different approach when addressing another area of Islamic marriage law with deep roots that has proven highly controversial in modernity: the area of child marriage. Before describing the Code's treatment of this highly contentious issue, however, it is important to review the historic rules.

\section{Child Marriage in the Traditionalist, Juristic Texts}

\author{
a. Age of Majority
}

\begin{abstract}
secular forces, Shi' a and Sunnis - that a child born to an Iraqi man and a non-Iraqi woman must be entitled to Iraqi citizenship by right, without any sort of restriction imposed respecting the religion of the woman in question. See id.

119 A well-publicized example of this is provided in the case of Margaret Hassan, a woman who married a Shi'i Iraqi when he was studying abroad, and then moved to Iraq and obtained dual citizenship but never converted to Islam. James Sturcke, Iraqi Sentenced to Life in Prison for Murder of Aid Worker Margaret Hassan. THE GUARDIAN (June 2, 2009), http://www.theguardian.com/world/2009/jun/02/margaret-hassan-iraq-murdersentence. When she was kidnapped and murdered in 2004 by a Sunni extremist organization, there were large demonstrations protesting her death, and substantial numbers of Iraqis were outraged. Id. The justice system continued to pursue the case, finally convicting someone of the murder in 2009 and sentencing him to life in prison. To say the least, it would have been an act of political folly for a draft Personal Status Code not to recognize the validity of her marriage, or the marriages of others like her.
\end{abstract}


Two relevant sets of rules exist in the traditional juristic formulations across the Islamic schools. The first is that the age of "adulthood"-the age at which one can marry and even consummate a marriage - is set at a much lower age than it is in modern states. Describing the rules across schools, Kecia Ali indicates that the date is set at puberty. ${ }^{120}$ Rudolph Peters says the same, though he adds minimum and maximum ages before which puberty cannot be established and after which it is presumed as a matter of law across the schools. ${ }^{121}$

The Shi'i texts support these conclusions for boys, indicating that first ejaculation or the appearance of pubic hair signifies puberty. ${ }^{122}$ They set no minimum age at which this might occur, but impose a maximum of fifteen years at which a boy is defined as an adult as a matter of religious law. ${ }^{123}$ For girls, however, the age the Shi'i jurists set is at nine lunar years, which is of course much lower than allowed in most modern states and is also set entirely independently of a girl's menarche or any other signs of puberty. ${ }^{124}$

\section{b. Marriage before Legal Age of Majority}

The second set of rules relating to child marriage is that across the Islamic schools, the guardians of children in their legal minority, and especially their fathers and paternal grandfathers, long had the power to contract them into marriage. ${ }^{125}$ As discussed below, this raises two very significant and obvious concerns. These are, respectively, the lack of consent from the girls and the likelihood that physical harm will occur to the girl upon consummation of the marriage. Each of these is discussed below.

\section{i. Problems of Consent}

The first concern is that this type of marriage effectively strips the right to consent to marry away from the children whose guardians contracted them into marriage. This does not seem consistent with the balance of the marriage rules because, generally speaking, jurists have long deemed the consent of an adult

120 ALI, supra note 6, at 32.

121 Rudolph Peters, Crime and Punishment in Islamic Law: Theory and PRACTICE FROM THE 16TH TO THE 21ST CENTURY 21 (2005).

122 JAWAHR, supra note 51, 26:5-6; KHU'I, supra note 68, 2:179.

123 JAWAHIR, supra note 51, 26:16; KHU'I, supra note 68, 2:179.

124 JAWAHIR, supra note 51, 26:38; KHU'I, supra note 68, 2:179; SISTANI, supra note 51, 2: $\$ 1069$. This is at slight variance with Peters, who suggests that a girl under nine might be deemed an adult upon menstruation. PETERs, supra note121, at 21 . The difference is largely academic, however, as the onset of puberty before the age of nine lunar years seems generally unlikely as a matter of fact.

125 TUCKER, supra note 4 , at 43. 
woman, virgin or non-virgin, necessary for a sound marriage. ${ }^{126}$ However, for some reason, the jurists treated the matter of children differently. Children's adult guardians plainly could contract them without their consent into marriage, though there are important limitations and qualifications. ${ }^{127}$

Hence, Grand Ayatollah Muhsen al-Hakim - the primus inter pares of Najaf's Grand Ayatollahs when Iraq enacted its current Personal Status Code in 1959-indicated that contracting a marriage for a minor was permissible, though it was reprehensible. ${ }^{128}$ He indicated that instead one should actually rush to marry a girl upon her reaching the age of adulthood of nine lunar years, on the basis of a report from Shi'i Islam's Third Imam that "it adds to the happiness of a person that his daughter does not menstruate in his home." 129 Other twentieth century jurists do not describe the child marriage as reprehensible, though they also do not indicate the same level of haste respecting the marriage of one deemed an adult, either.

Generally, under the traditional Shi'i rules, a girl's father or paternal grandfather has the power to contract her into a marriage. If her brother or uncle undertakes it, in the event that the father or paternal grandfather are deceased or otherwise incapable, then the girl must consent to the marriage upon becoming an adult in order for the marriage to be deemed valid. ${ }^{130}$ Similarly, if a father or paternal grandfather has a corrupt purpose in undertaking the marriage, then the marriage contracted requires the consent of the girl when she becomes an adult (i.e., at the attainment of nine lunar years), as if an uncle or brother had contracted the marriage instead. ${ }^{131}$ The jurists do not define with any level of specificity what they mean by a "corrupt purpose," though presumably it might include contracting a girl into marriage for a lower than normal dower in exchange for a personal payment from the husband or his family directly to the guardian. ${ }^{132}$

$126 \quad I d$.

$127 \mathrm{Id}$.

128 MUHSEN IBN MAHDI TABataba'I AL-HAKIM, 14 MUSTaMsIK AL-URWA ALWUTHQA 11 (1983).

129 Id.

130 JAWAHIR, supra note 51, 29:203, 217; SISTANI, supra note 51, 3: 957(indicating that the father and grandfather have the power of guardianship as concerns marriage), $₫ 73$ (indicating that a marriage contracted by a person other than a guardian or an agent depends on the acceptance when the party being married consents); HAKIM, supra note 128, 14:43637.

I31 See, e.g., KHU'I, supra note 68, 2:ๆ1236; HAKIM, supra note 128, 14:455-56.

132 Shi'i jurists contrast the power of a father or grandfather on the one hand, with the power of other guardians on the other, by pointing out that with a father or grandfather, the absence of a corrupt purpose is presumed, while in the case of other guardians, the presumption is that the marriage is contracted in pursuit of a personal interest. This presumption justifies the power of the father or grandfather to compel a marriage that a different guardian could not compel upon the attainment of adulthood. See, e.g., JAWAHIR, supra note 51,29:197. The rule set forth in the main text that a father or grandfather with a corrupt purpose cannot compel the marriage when the child is an adult can therefore be 
Moreover, as a matter of precaution, both Hakim and Sistani indicate that the father or grandfather must perceive a benefit in the marriage. ${ }^{133}$ In other words, the marriage is not valid unless there is an absence of a "corrupt purpose" and there is some affirmative reason to undertake the marriage at such a young age. Hence, Hakim indicates that if two people wish to marry a man's daughter, and he chooses a less honorable groom over one who offers a lower dower, then the validity of the marriage is thrown into doubt. ${ }^{134}$ Practically, the "doubt" means a sufficient uncertainty concerning the validity of such a marriage that it should be clarified through marriage or divorce. ${ }^{135}$ The same rules apply for a boy contracted into marriage as for a girl. ${ }^{136}$

A dispute arises, however, as to whether the contract is binding without a determination of a "corrupt purpose" and where the father or grandfather can claim some sort of benefit in the marriage. In other words, if a father contracts his four-year-old son or daughter into a marriage with a husband who would broadly be deemed suitable, and on a socially acceptable dower, is the marriage binding upon the boy or girl should he or she seek to disavow it upon reaching adulthood? The nineteenth century Jawahir states the contract is absolutely binding on the girl and most probably on a boy as well, indicating that a girl's hatred of her contracted husband is not a reason to fail to obey her father's dictate. ${ }^{137}$ Hakim similarly binds the girl absolutely and indicates that the better opinion is that the boy is also bound to a contract arranged by a father or grandfather. ${ }^{138}$

Sistani takes a narrower view. He indicates that if a father or paternal grandfather contracts a marriage for a child, male or female, it is valid absent a "corrupt purpose" and the existence of a personal benefit. ${ }^{139}$ However, he adds that the validity of the marriage "might depend on the establishment of an election for the contracted party after adulthood and discernment."140 If a woman disavows a marriage her father or paternal grandfather contracted for her when she was a child, then sufficient doubt exists as to the initial validity of the contract, meaning that the contracted parties must either renew their wedding vows or the

seen as merely a logical extension of that same rule. That is, where an uncle would be presumed to be contracting his niece into marriage for his own personal benefit rather than hers, a father would be presumed not to do this as with his own son or daughter. If he were found to be pursuing a "corrupt purpose," however, then the marriage he contracts would be subject to invalidation by the child upon reaching adulthood, precisely as the contract by an uncle would.

133 HAKIM, supra note 128, 14:455-56; SISTANI, supra note 51, 3:59.

134 HAKIM, supra note $128,14: 456-57$.

135 Sistani lays out these alternatives in explicit detail. See SISTANI, supra note 51, 3: \60.

136 JAWAHIR, supra note 51, 29:203, 217; SISTANI, supra note 51, 3: ๆ57, 973 ; HAKIM, supra note $128,14: 436-37$.

137 JAWAHIR, supra note $51,29: 172-73,182$.

138 HAKIM, supra note 128, 14:433-34.

139 SISTANI, supra note 51, 3: 960.

140 Id. 
husband must pronounce a divoree. ${ }^{141}$ This gives an adult woman the ability to disavow a marriage contracted without her consent, given that her husband cannot claim any benefits from the marriage unless he resolves the doubts surrounding the marriage's validity, and given that those doubts can only be resolved with the wife's consent to the marriage.

\section{ii. Physical Harm}

Beyond the lack of consent, another looming problem in contracting girls into marriage before they reach the age of majority is the actual, physical harm they are susceptible to from sex during childhood, or even worse, during infancy. In deference to those concerns, there is broad agreement among Shi' $i$ jurists that a husband cannot consummate his marriage to a girl under the age of nine lunar years, i.e., a girl who has not reached the technical age of majority. ${ }^{142}$ The specific reason given is the inability of a girl that age to be able to physically tolerate penetration. ${ }^{143}$ Consummation includes both anal and vaginal sex, but it does not refer to "enjoyment" other than sex. ${ }^{144}$ To quote Sistani, "there is no problem with ... touching with appetite, kissing, embracing, and thighing."145 Hakim reaches a largely similar conclusion, indicating that such sexual enjoyments are available even with a child who is young enough to be still nursing. ${ }^{146}$

A problem occurs when a husband ignores this directive and penetrates his child wife before she reaches the age of nine. There is some source text that suggests that after such penetration, the husband may never engage in sexual intercourse with the girl ever again. However, jurists in the modern era have rejected this source text in favor of alternative text, which holds that there are no financial or legal consequences to the commission of this $\sin ^{147}$ The exception is if the sex causes "ripping," whose precise definition the jurists dispute, but which at its core refers to the tearing of a girl's genital area through sexual penetration

$141 \quad I d$.

142 JAWAHIR, supra note 51, 29:414; HAKIM, supra note 128, 14:78-79; SISTANI, supra note 51, 3: ๆ8; KHU’, supra note 68, 2: ๆ1230.

143 JAWAHIR, supra note 51, 29:415.

144 Id. at 29:416.

145 SISTANI, supra note 51, 3: $₫ 8$.

146 HAKIM, supra note $128,14: 79-80$. The final of these so-called enjoyments, referred to by Sistani and Hakim alike as "thighing," is no more a word in Arabic than it is in English. It is the creation of a verb from the noun "thigh." The Grand Ayatollahs leave it to the reader's imagination as to what this refers, though the matter seems not terribly difficult to discern.

147 See JAWAHIR, supra note 51, 29:417-19 (describing the rule, and the texts which support a different conclusion); HAKIM, supra note 128, 14:80-82 (describing same in text and accompanying footnotes). See also SISTANI, supra note $51,3: q 8$. 
such that one of the urinal, vaginal, or anal pathways combines with one or more of the other. ${ }^{148}$

In the case of "ripping" a girl, modern jurists take the position that the husband owes her blood money for the injury, whether or not he divorces her, despite some earlier disagreement in source texts which suggested that no blood money was due if the woman remained married to the man. ${ }^{149}$ The blood money for a free Muslim woman works out to approximately $\$ 100,000$-a significant sum in Iraq. ${ }^{150}$ If the "ripping" occurs when the husband consummates the marriage and the girl is older than nine lunar years, the modern jurists seem to agree that no blood money is due because the girl is considered an adult. ${ }^{151}$ Intercourse is forbidden with a "ripped" wife if her husband injured her before she was nine, at least until her wound heals. ${ }^{152}$ Intercourse with a wife "ripped" after the age of nine, however, is permissible. ${ }^{153}$

However, whether the ripping occurs before or after consummation, certain legal consequences of the marriage remain forever. Specifically, the wife inherits from the husband as his spouse, he cannot marry her sister so long as she is alive, he cannot take four wives in addition to her, and, most importantly, he must support her financially. ${ }^{154}$ While these are the regular consequences of marriage, they usually cease to exist after a divorce. In the case of a "ripped" wife, however, they remain in place, even if there is a divorce.

\section{Child Marriage in the Draft Ja'fari Code}

Liberal and secular forces within Iraq and beyond it would plainly find such rules horrifying in the extreme, even more so than temporary marriage. Where the human rights implications of the consensual barter of sexual enjoyment for money as contemplated by the temporary marriage are at least ambiguous, ${ }^{155}$ condemnation of child marriage around the globe is broad and deep. ${ }^{156}$

148 See JAWAHIR, supra note 51, 29:419-21 (describing the definitional issues in some detail); HAKIM, supra note 128, 14:85-86 (also describing the definitional issues in detail). See also SISTANI, supra note 51, 3: 18.

149 See JAWAHIR, supra note 51, 29:422-23(describing the dispute); HAKIM, supra note 128, 14:83-84 (also describing the dispute). See also SISTANI, supra note 51, 3: 98 .

150 See infra notes $168-85$ and accompanying text (offering a fuller description of the blood money and the manner by which it is calculated).

151 SISTANI, supra note 51, 3: ๆ8; JAWAHIR, supra note 51, 29:422

152 HAKIM, supra note 128, 14:83; SISTANI, supra note 51, 3: ๆ8.

153 HAKIM, supra note 128, 14:88; SISTANI, supra note 51, 3: $\mid 8$.

154 JAWAHIR, supra note 51, 29:435-36; SISTANI, supra note 51, 3: ๆ8; HAKIM, supra note $128,14: 84,91$.

155 The rules of temporary marriage would create some problems for liberals, even those who might favor legalized forms of prostitution. For example, while clearly a woman's consent is necessary when she is an adult in order to engage in the temporary marriage, in many cases a father's consent is necessary as well. See SisTANI, supra note 
That Iraqi liberals had powerful global allies on this question leads one to think that the drafters might defer to liberal expectations. However, this law was neither drafted to appeal to Muslim liberals, nor human rights activists, nor even the broader international community. It sought to appeal to one, and only one, constituency-Muslim social conservatives in Iraq. As such, the draft Code adopts a version of child marriage that in some respects replicates juristic rules, but in others departs from them significantly in a manner that renders them even less protective of girls than the already problematic juristic rules.

The rules concerning the age of adulthood largely replicate those of Sistani. They are buried in the section addressing wills, in what appears to be a clumsy and amateurish attempt to make them more difficult for opponents to locate. Nevertheless, Article 16 clearly states a definition of puberty for girls at nine lunar years and for boys "fifteen lunar years or the realization of one of the bodily signs depended upon by the jurists of the Muslims to establish puberty among males." 157

Far more interesting are the provisions concerning the marriage of children by their guardians. Articles 43(6), 50, and 51 together read as follows:

Article 43: The soundness of a contract for marriage depends on the following conditions:

(6) That the contracting party is an adult and sane, hence neither the contract of an insane person nor the contract for a discerning child for himself is sound without the permission of the guardian (the father and the paternal grandfather).

Article 50: The father and the grandfather from the side of the father when sane and Muslim exclusively have the power to marry the small child, male and female, or the insane person whose insanity runs through puberty.

Article 51: The soundness of the marriage of a father or paternal grandfather depends on the absence of a corrupt purpose, and the realization of best interest in the contract of

51, 3:ๆ68. Still, the concept of a consensual arrangement that involved money for sex might not be deemed to necessarily offend liberal sensibilities in a way that a child marriage surely would.

156 To take the simplest example, the Universal Declaration of Human Rights specifically requires that marriage only be entered into "with the free and full consent of the intending spouses." G.A. Res. 217 (III) A, Universal Declaration of Human Rights, at art. 16(2) (Dec. 10, 1948). A similar provision is contained in Article 23 of the International Convention on Civil and Political Rights, to which 168 nations are party. International Convention on Civil and Political Rights at art. 23, Dec. 16, 1966, S. Treaty Doc. No. 9520, 6 I.L.M. 368 (1967), 999 U.N.T.S. 171.

157 Draft Ja'fari Code, supra note 42 , at art. 16. 
marriage. Without it, the soundness of the contract depends on the acceptance of it from the child after puberty or the insane after recovering sanity. ${ }^{158}$

This is largely a repetition of Sistani's rules, with two important variations. First, nowhere does it suggest, as Sistani does, that there is doubt as to the soundness of a marriage that a child disavows at puberty as a general matter, even if the father had the child's best interests in mind. ${ }^{159}$ The Code drafters, that is, seem to prefer the rules of the earlier jurists, which indicate that a father or grandfather can compel a child into marriage, whether or not the child disavows the marriage at puberty. ${ }^{160}$ Thus, the drafters had an opportunity to at least ameliorate some of the concerns of liberals and their allies in the international human rights community merely by replicating Sistani's rules and requiring the consent of the marrying parties when they reach the age of adulthood. However, they chose to ignore Sistani and use the rules of other jurists instead that prove even more problematic from a liberal perspective.

As to why the drafters did this, the reasons seem clear enough. If the aims of the law are to appeal to forces of social conservatism within Iraq, then it is well established that child marriage is practiced in socially conservative communities, and its prevalence has only risen in recent years. ${ }^{161}$ The fathers and grandfathers in such communities would hardly want a court to entertain a claim from their child upon reaching puberty that the child disavowed the marriage contracted for the child. Hence, Sistani's comparatively progressive rule was struck in favor of more conservative juristic approaches.

Such an approach is defensible as a realization of Shi'i rules, given the juristic disagreement as between Sistani and other, leading jurists in the modern era. However, the second change to the juristic rules is not. Specifically, the draft Code omits any reference to a prohibition against penetrating a girl before she reaches nine or attaching consequences if this is done. No jurist has failed to mention this specific prohibition. There may be two reasons for this omission on the part of the drafters. The first possibility is that the drafters feared some level of backlash by including these rules. After all, if they are to indicate that penetration of a six-year-old is a sin, they must also indicate that "thighing" her is not one. Similarly, they must then describe the legal and financial consequences

$158 \quad$ Id.at arts. $43,50,51$.

159 SistanI, supra note 51, 3:ๆ60. See also supra notes 122-26 and accompanying text.

160 See JAWAHIR, supra note 51, 29:172-73, 182; HAKIM, supra note 128, 14:433-34.

161 Iraq Woman Integrated Social and Health Survey, Ministry of Planning, Central Statistical Organization (March 2012), http://iraq.unfpa.org/en/publications/ doc_download/16-iraq-woman-integrated-social-and-health-survey-i-wish; See also Gordon Brown, Child marriage could become law in Iraq, but it's a global scourge, THE GUARDIAN (Apr. 29, 2014, 5:00 PM), http:/www.theguardian.com/commentisfree/2014/ apr/29/gordon-brown-child-marriage-iraq-barbaric. 
if there is in fact penetration that causes "ripping." This would call more unwanted attention to the matter than merely omitting all of these rules might.

This explanation seems unlikely. If the drafters actually cared about global opinion, they could have omitted any mention of child marriage as they largely did with temporary marriage, or they could at least have rendered its validity dependent on consent at adulthood, as Sistani does. The more likely possibility is that the drafters thought that social conservatives might very well wish to engage in sexual intercourse with five-year-old girls, and would naturally not want significant financial consequences to attach to whatever followed by way of permanent physical damage done to the girl. They thus sought to appease such forces, at the expense of the girls so harmed.

This is of course supposition. What is clear is that whatever the reasons for the omissions under the draft Code, a man can marry a girl of any age with her father's consent, cause any amount of damage to her, and escape any financial consequences. This is quite clearly a significant departure from core doctrinal principles established by the jurists. The drafters are ignoring obligatory wealth transfers, rendering prohibitions as permissible, and setting aside matters of right, all in order to satisfy socially conservative forces. Whatever the Code might be, it most certainly is not a faithful rendition of the rules of Shi'ism.

\section{REORDERING THE ISLAMIC LAW HIERARCHY: TRIBES OVER JURISTS}

The matters of both temporary marriage and child marriage involve circumstances where the drafters of the Ja'fari Code chose to ignore particular aspects of Islamic law that social conservatives did not like, while enacting those aspects that appealed to them. The drafters did more than this however. They also in some cases stripped the jurists of their authority to determine, on an exclusive basis, the content of Islamic law for the Shi'a. This is deliciously ironic, given that it was this authority that led to the objections to the existing Personal Status Code in the first place. ${ }^{162}$ An excellent example lies in the case of calculating the size of an estate upon death.

By way of background, the shari'a across Sunni and Shi'i schools does not grant to individuals the right to distribute their assets upon death in any manner they prefer. Instead, by operation of law, it mandates that the assets be divided into specified portions to be given to designated individuals who are usually family members, such as children, spouses, parents and siblings of both genders. ${ }^{163}$ However, a decedent is given the ability to dispose of up to one-third of his or her assets by bequest. ${ }^{164}$

\footnotetext{
162 See supra notes 31-34 and accompanying text.

163 JAMAL J. NASIR, THE Islamic Law OF PERsonal Status 197 (3d ed. 2002).

$164 \quad I d$.
} 
In determining the size of the estate out of which one-third can be bequeathed, Shi'i jurists included not only assets that the decedent acquired before death, but also those acquired afterwards. ${ }^{165}$ A common example given in the juristic texts is something that is caught in a net that the decedent had set up before death but which was not caught until after death. ${ }^{166}$

Blood money is also included in the estate. ${ }^{167}$ Blood money is due to a decedent if someone intentionally or accidentally kills or injures the decedent. ${ }^{168}$ Across the various Islamic schools and sects, the amount that is due varies depending on the intent associated with the killing or injury, and the gender, religion, and status of the victim. ${ }^{169}$ For example, within Shi'ism, intentionally killing a free, ${ }^{170}$ Muslim man requires the payment of either one hundred specified high quality camels, ${ }^{171}$ two hundred cows, ${ }^{172}$ one thousand sheep, ${ }^{173}$ two hundred fine garments each consisting of two shirts, ${ }^{174}$ one thousand dinars (minted gold coins), ${ }^{175}$ or ten thousand dirhams (minted silver coins). ${ }^{176}$ The deliberate flexibility in forms of payment enables parties living in different areas to be able to pay with items valued in their region. ${ }^{177}$ To give some rough sense of the value, a dinar is approximately $75 \%$ of the weight of a mithqal of gold. ${ }^{178}$ Six and

165 SISTANI, supra note 51, at 2: \1381; KHU'I, supra note 68, at 2: ๆ1015; HAKIM, supra note 128 , at $617-20$.

166 SISTANI, supra note 51, at 2: ๆ1381; KHU'I, supra note 68, at 2: ๆ1015; HAKIM, supra note 128 , at 617 .

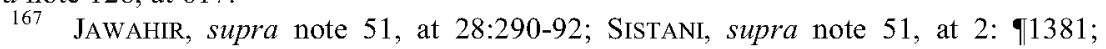
KHU'I, supra note 68, at 2: 91015 ; HAKIM, supra note 128, at 617.

168 The compendia indicate that all blood money that is paid-whether for intentional or accidental death, or for injury - are calculated in the estate. See JAWAHIR, supra note 51, 28:290-91; SISTANI, supra note 51, at 2: 11381 ; KHU'I, supra note 68, at 2: \1015; HAKIM, supra note 128, at 619-20; see generally JAWAHIR, supra note 51.

169 See PETERs, supra note 121, at 49-53 (setting forth the rules across the various Islamic schools); JAWAHIR, supra note 51, at 43:2-454 (laying out the Shi'i rules in excruciating and often arcane detail). See also supra Part II.C.1.b.ii for an example where blood money would be due to a child wife if a husband causes her severe injury during sexual intercourse.

170 I have omitted the rules respecting blood money for slaves in the interests of brevity. For further information on Islamic slavery, see infra Section V.A.

171 JAWAHIR, supra note 51, 43:4; KHU'I, supra note 68, 3: ๆ203.

$172 I d$.

$173 I d$.

174 JAWAHIR, supra note 51, at 43:4, 10 (taking the position that the garments have to be from Yemen); KHU'I, supra note 68, at 3: I203 (arguing that the garments need not be from Yemen).

175 JAWAHIR, supra note 51, at 43:11; KHU'I, supra note 68, at 3: 1203.

176 JAWAHIR, supra note 51, at 43:4; KHU'I, supra note 68, at 3: 1203.

177 JAWAHIR, supra note 51, at 8-9.

178 KHU'I, supra note 68, at 3: 9203. 
two-thirds mithqal weighs an ounce. ${ }^{179}$ Thus, 1000 dinars are equal to 750 mithqal, which is about 112.5 ounces of gold. The price of gold has varied over the past decade from about $\$ 1000$ per ounce to $\$ 2000$ per ounce, ${ }^{180}$ placing the value of blood money owed for an intentional homicide between $\$ 112,000$ and $\$ 224,000$. When one accidentally kills the decedent, whether negligently or not, one must pay the same amount. However, if the blood price is paid in camels, the quality of the camels is lower. ${ }^{181}$ In each case, the blood price of a woman is half of that of an equivalent man. ${ }^{182}$ A schedule is set for the blood money due for an intentional and unintentional injury to an organ. For example, each eye and ear is worth half of a full blood price, ${ }^{183}$ whereas a tongue or a nose is worth the full blood price. ${ }^{184}$

The main difference between intentional and unintentional killing and injury is the absence of an option for retribution when there is no intent. ${ }^{185}$ In other words, with an intentional killing or injury, a victim (or a decedent's representatives) may demand retribution by inflicting the same injury on the perpetrator, rather than receiving blood money. To quote the Jawahir:

[Retribution] means here the satisfaction of the effect of the crime, whether it be killing, severing, striking or injuring. The one seeking retribution mimics the effect of the crime, and does the same to him. ${ }^{186}$

Thus, a Muslim man could cut the tongue of another Muslim man who cut his. Similarly, a Muslim woman could cut the tongue of a Muslim man who

179 Marion Johnson, The Nineteenth Century Gold 'Mithqal' in West and North Africa, 9 J. OF AFR. Hist. 547, 548 (1968).

180 Tables are readily available on the Internet that reflect the price of gold over the past five years or longer. See, e.g., GOLDPRICE, www.goldprice.org (last visited Mar. 26, 2016).

181 KHU'I, supra note 68, at 3: ๆ 209-10. There is an intermediate form of intent, roughly equivalent to recklessness, which I do not discuss in the main text. Suffice it to say, the blood money is basically the same for such reckless killing as it would be for intentional and unintentional killings as per above, though if paid in camels, the quality of the camels lies between the high quality camels due for an intentional killing, and the somewhat lower quality camels due for an unintentional one. See JAWAHIR, supra note 51, 43:17-18.

182 JAWAHIR, supra note 51, at 43:32 (respecting Muslim women), 39 (respecting non-Muslim women); KHU'I, supra note 68, at 3: 1213 (respecting Muslim women), at T215 (respecting non-Muslim women).

183 JAWAHIR, supra note 51, at 43:181, 200; KHU'I, supra note 68, at 3: 19279, 283.

184 JAWAHIR, supra note 51, at 43:190, 209; KHU'I, supra note 68, at 3: ๆ282.

185 JAWAHIR, supra note 51, at 43:3; KHU'I, supra note 68 , at 3: $\mid 226$.

186 JAWAHIR, supra note 51 , at $42: 7$. 
intentionally cut hers, but she would have to pay half of the blood price first to make up for the difference in blood money between her and the perpetrator. ${ }^{187}$

There are obvious human rights concerns associated with these rules, but considerably comforting to liberal and secular forces within Iraq is that fact that these rules bear no resemblance to the manner in which such matters are addressed as a matter of fact. Rather, there are two effective systems to deal with intentional and unintentional injury in Iraq. The first is the state's legal system, and the second is the tribal law. ${ }^{188}$

The former is broadly relevant as concerns the application of criminal law, and it is the product of Western transplant, not shari' $a .{ }^{189}$ There is thus no such thing as a retributive injury elected by a victim in the Penal Code. The state can pursue the death penalty for murder, but if it does not, then a jail term is the alternative. ${ }^{190}$ Similarly, for other injuries, the punishments are jails and fines, not the amputation of limbs and the severing of bodily organs. ${ }^{191}$

Concerning compensation for an injury, Iraq has developed an entire tort system that entitles a victim to compensation for material and nonmaterial harm that another person caused them through a "fault" on the part of the perpetrator. ${ }^{192}$ Fault is explicitly limited to circumstances where the perpetrator intends the injury, or negligently causes it. ${ }^{193}$ When the resulting injury is death, then the victim's estate may recover for any material harm suffered by the victim, and the victim's family may recover for emotional harm and mental distress as well. ${ }^{194}$ The goal is thus to compensate for harm actually incurred. ${ }^{195}$ Given this, the idea that somehow the amount of recovery would be based on gender, or that an injury to a nose would be compensated at the same level as a wrongful death, runs contrary to the very logic of the system, which compensates based on actual harm, not what body part has been damaged.

This means of addressing injuries to the person, complete with elements of causation, ${ }^{196}$ the standard of the reasonable person for negligence, ${ }^{197}$ and the notion of recovery for emotional distress and mental anguish, ${ }^{198}$ would be familiar

187 KHU'I, supra note 68, 3: $\$ 162$ (giving the example of a severed hand).

188 Haider Ala Hamoudi, Decolonizing the Centralist Mind: Legal Pluralism and the Rule of Law in THE INTERNATIONAL RULE OF LAW MOVEMENT: A CRISIS OF LEGITIMACY AND THE WAY FORWARD 135, 148-54 (2014).

189 Haider Ala Hamoudi, Religious Minorities and Shari'a in Iraqi Courts, 31 B.U.

Int'1 L.J. 387, 403 (2013).

190 Penal Code No. 111 of 1969 , arts. 405-06 (Iraq).

19l Id. at arts. 412-13.

192 Civil Code No. 40 of 1951 (Iraq), arts. 202-05.

193 Abdul Majid al-Hakim, A Summary of the Theory of Obligation in the Iraqi Civil Code 1:215(1980).

194 Civil Code No. 40 of 1951 (Iraq), arts. 203, 205.

195 HAKIM, supra note 128 , at 1:201.

196 Id. at 1:239-40.

197 Id. at $1: 215$.

198 Id. at $1: 212$. 
to any modern civilian or common law lawyer, even as it is entirely alien to the jurists of Najaf. And it has been the state's formal means of adjudicating disputes since the promulgation of the Civil Code in 1951. Countless numbers of cases are decided annually on the basis of this standard. ${ }^{199}$

The other manner in which injuries are addressed within Iraq is through use of the tribal law. This system is not used to punish wrongdoers (though blood feuds can erupt), ${ }^{200}$ so much as ensure that victims are compensated for their injuries. The processes begin with an informal notification initiated by one tribe to a second, effectively informing them that in its view, a member of the second tribe has caused injury to one of the first. ${ }^{201}$ If that does not satisfy the injured tribe, then it makes a formal, sterner demand, known among the Iraqi tribes as a guama, ${ }^{202}$ in public view, both to shame the other tribe into negotiating a resolution and to warn of future sanctions should the tribe continue to refuse. ${ }^{203}$ Most tribes against which a guama is initiated seek resolution soon thereafter if they think one of their members is indeed responsible for an injury. ${ }^{204}$ This is because a tribe against which a claim is made is well aware that it might have a claim to make in the future, and hence there is little advantage in developing a reputation for recalcitrance. ${ }^{205}$ In the minority of cases where there is no agreement to resolve, the matter is escalated to what is known as the $\operatorname{degga}$, $^{206}$ which involves spraying the house of the perpetrator with bullets when nobody is expected to be home. ${ }^{207}$ Much like the guama, this serves both as reputational sanction (as the bullet holes are rather obvious to any onlooker) and as a warning of further repercussions, albeit in a far more confrontational fashion than the guama. $^{208}$ The degga can be repeated any number of times, with increasing levels of threatened violence. ${ }^{209}$

At some point during this process, one of three outcomes will ensue. The injured party might relent. This is unusual. However, it could occur if the allegedly offending party demands an arbitration of the matter, and the parties agree on an arbitrator who finds that the injury is not the responsibility of the

199 Hamoudi, Decolonizing the Centralist Mind, supra note 188 , at 151.

200 Hamoudi, Al-Sharaa \& Al-Dahan, supra note 109, at 250 (noting a rather widespread blood feud that erupted in Basra in 2010 between two rival tribes).

201 Hamoudi, Decolonizing the Centralist Mind, supra note 188, at 151.

202 The word is an Iraqi dialectical form of the classical Arabic verb qawama, which means to resist or to combat. The idea is that the offended tribe is fighting back, in a sense, against the wrong done to it. HANS WEHR, A DICTIONARY OF MODERN WRITTEN ARABIC 934 (J. Milton Cowan ed., 4th ed. 1994).

203 Hamoudi, Decolonizing the Centralist Mind, supra note188, at 152.

204 Id.

$205 \mathrm{Id}$

206 This term is an Iraqi dialectical form of the classical Arabic verb daqqa, meaning to pound, strike or beat. WEHR, supra note 202, at 331 .

207 Hamoudi, Decolonizing the Centralist Mind, supra note 188, at 152.

208 Hamoudi, Alsharaa \& al-Dahan, supra note 109, at 235.

209 Id. at 15; Hamoudi, Decolonizing the Centralist Mind, supra note 188, at 152. 
allegedly offending party. ${ }^{210}$ The second possibility is that a full-fledged feud develops between the tribes. Parties normally avoid this option because it results in levels of violence that can attract state attention. ${ }^{211}$ Finally, the offending tribe can relent, and request a respite, or atwa, to gather its members. ${ }^{212}$ Following this, the offending tribe pays a visit to the home of the injured member of the other tribe to discuss compensation. ${ }^{213}$ These discussions, to the extent they involve a lost life, refer to the blood money that injured parties can demand, usually in the form of sheep. ${ }^{214}$ Eventually, after much pleading and discussion, the tribes settle on a sum, which is usually paid immediately in cash. ${ }^{215}$ In more remote areas, the settlement can involve the trading of women as well, where a woman from one tribe is delivered to another to compensate for an injury done to it. ${ }^{216}$

This is but a summary rendition of the rich and complex area of Iraqi tribal dispute resolution, but it is sufficient to demonstrate important differences from the Islamic law of homicide and wounding. Nonphysical, moral injuries, like defamation or slander, are quite commonly those for which tribes demand compensation, given the importance of preserving honor among them. ${ }^{217} \mathrm{By}$ contrast, the Shi'i jurists make no mention of such nonphysical injuries, nor does the system they have created seem to allow space for them, given the lack of any sense in inflicting a retributive injury or ascribing a "blood price" to reputation, as opposed to an organ or a limb. In addition, many types of settlement, including the trading of women, have no Islamic analogue. A perpetrator may pay blood money in any of a number of forms under the Shi'i rules, but the offering of women for marriage is not one of them. ${ }^{218}$ Finally, and perhaps most importantly, the looming threat under which the negotiations take place in Islamic law is the exacting of physical retribution, at least for intentional harms, ${ }^{219}$ and not the reputational sanctions that appear to motivate the tribe. ${ }^{220}$

It is just as important to note that within Iraq, there is no significant social or political movement that seems interested in implementing the Islamic

210 Hamoudi, Al-Sharaa, \& Al-Dahhan, supra note 110 , at 22; see also Hamoudi, Decolonizing the Centralist Mind, supra note 188, at 151-52.

211 Hamoudi, Al-Sharaa, \& Al-Dahhan, supra note 109, at 27.

212 Hamoudi, Decolonizing the Centralist Mind, supra note 188, at 152.

213 Hamoudi, Al-Sharaa, \& Al-Dahan, supra note 109, at 238.

214 Interview with Sheikh Mazen Falih Muhammad al-'Araiby, clan elder of the Muhammadawi tribe, in Sadr City, Iraq (April 25, 2013).

215 Hamoudi, Al-Sharaa \& Al-Dahhan, supra note 109, at 238-39.

216 Id. at 27.

217 See id. at 22 (pointing out that slander is one area that tribes insist they address entirely on their own, without, state court involvement).

218 See supra notes $168-85$ and accompanying text (describing different mediums that can be used to pay blood money due).

219 See supra notes 185-90 and accompanying text (describing retributive injuries).

220 Hamoudi, Al-Sharaa \& Al-Dahhan, supra note 109, at 14-15 (noting importance of reputation among tribes). 
system concerning homicide and physical injury to the person. ${ }^{221}$ Liberals and secularists who live overwhelmingly in the large cities obviously prefer the existing transplanted state system. The tribes that make up an important part of the socially conservative constituency in urban shantytowns and rural areas throughout $\operatorname{Iraq}^{222}$ likewise have no interest in an Islamic state system. If they did, they would already be implementing an Islamic system on their own rather than relying on tribal law.

The drafters of the Ja'fari Personal Status Code thus had three options. The first, which would be the way of Islamic purity, would be to include blood money in the value of an estate, and then leave to future legislators the task of reforming tort law to define what blood money is and how to calculate it. Another way would be to placate liberals by simply indicating that the value of the estate includes wealth acquired by the decedent after death, including any amounts accruing to the decedent by virtue of someone causing the decedent's death. This would hardly be endorsing the current state system for determining redress for injury. After all, the amounts referred to as arising out of murder or accidental killing could be blood money just as easily as they could be ordinary damages for wrongful death. But, at least such a provision would recognize state law enough as to permit a person to bequeath amounts that the estate receives after death through the adjudication or settlement of a modern tort claim.

Yet as we have seen time and time again, the draft Code was not meant to placate liberals, nor was it drafted to actually implement Islamic law in any recognizably "pure" form. Rather, it was designed to satisfy socially conservative elements of Iraqi society. Therefore, the drafters opted for a different course. This was to defer to the tribes in their determinations of the proper understanding of Islamic law, to the derogation of the jurists. That is, the Code refused to recognize state law rules on wrongful death while simultaneously declaring tribal law as Islamic, despite its differences from Islamic law as articulated by the Najaf jurists. Specifically, Article 25 reads as follows:

The estate is calculated by what the person owned at his death, but what enters into his possession after death does not count, with the exception of the blood money for a mistaken or intentional killing, if the representatives of the decedent reconcile themselves to that. Within this is the tribal resolution, given that it is part of the blood money. ${ }^{223}$

This changes the juristic rules in two important ways. First, it generally excludes sums that would have accrued to the estate under juristic rules, such as the fish

221 The Death of Islamic Law, supra note 32, at 327.

222 Hussein D. Hassan, IraQ: Tribal Structure, Social and Political ACtIVITIES, CRS-1 (CONG. ReSEARCH SERV., RS22626, 2008).

223 Draft Ja'fari Code, supra note 42, at art. 25. 
caught after the death of the decedent in a trap the decedent had set. ${ }^{224}$ The effect of this is that if the state awarded compensation for wrongful death to a person, a court would not give effect to any a priori effort by that decedent to bequeath such funds. Perhaps the drafters found this appropriate because funds awarded for wrongful death by an Iraqi court applying a modern Civil Code are not Islamic in origin and thus deserve no recognition in a Shi'i Personal Status Code. As the drafters could not change the Civil Code, they merely changed the rule to render such sums unrecoverable, thereby arguably retaining the substance of the juristic rule, if not the form.

Yet, ironically, the drafters did not treat tribal resolutions the same way as state law judgments for wrongful death adjudicated under a more secular Civil Code, even though both are deviations from Islamic law. Instead, they declared tribal resolutions to be themselves the realization of Islamic principles respecting recovery of blood money. No qualification is given to this. In other words, the compensation awarded in a tribal resolution is by legal definition the payment of Islamic "blood money," even if it includes amounts that no jurist would ever describe as Islamic, and even if the tribal resolution is reached using processes that jurists would not recognize as Islamic. The tribes thus have as much right as the jurists to determine the content of Islamic law.

For a Code specifically drafted to realize the right of the jurists to set the law of personal status for the Shi'a, this is truly remarkable. It appears that the problem for the drafters of the Code with the existing Personal Status Code was not that it granted the power to determine the content of Islamic law to individuals other than the jurists. The draft Code does that as well. The problem instead is that it gave such power to the wrong people - specifically, progressives, rather than tribes intent on preserving existing hierarchies and structural iniquities.

\section{STRATEGIC JURISTIC OMISSION}

\section{A. On Islamic Slavery and the Nature of Juristic Omission}

This Article so far has focused on the means by which Iraqi lawmakers drafting a personal status code altered religious rules to meet the expectations of socially conservative forces whose claim of fealty to those same rules was more rhetorical than real. Yet it is not only purely political figures, such as lawmakers, who manipulate and prevaricate in order to change the substance of religious rules in order to comply with the demands of a constituency. Jurists do much of the same, as this Part will show.

It is important to distinguish this phenomenon from a juristic reassessment of the shari'a corpus that either explicitly or implicitly rejects, limits, or alters earlier rules based on alternative readings of source text. Such a for it).

224 See supra note 169 and accompanying text (describing rule and juristic support 
reassessment would simply be doctrinal evolution, no different from changes in constitutional understanding that occur in high courts around the world over the span of decades. ${ }^{225}$ Indeed, this Article points to one prominent example where such a reassessment appears to have taken place. Sistani suggests, in a manner that earlier prominent jurists did not suggest, ${ }^{226}$ that there is doubt as to the validity of a marriage arranged for a girl by her father if she disavows it at puberty. ${ }^{227}$ While Sistani does not explain the basis for his position or its variance with earlier determinations, the change is unmistakable.

That said, at least from the standpoint of a liberal, over the past two centuries, jurists have been broadly unwilling to undertake a serious and thorough examination of the rules they have derived, with the deplorable results described above relating to matters such as child marriage ${ }^{228}$ and the reduction of marriage to bartering over sexual access. ${ }^{229}$ Instead, quite often, rather than revisit particularly unattractive rules, they leave them not discussed. The jurist does not change the previous rule so much as reduce treatment of it in a fashion that almost misrepresents it. Alternatively, the jurist might just not discuss the rule at all, thereby leading the faithful who do not spend time reading compendia decades old unaware that such a rule could ever have existed within Shi'ism. I refer to these processes as "strategic juristic omission."

The most obvious example of this is slavery. The juristic compendia of all of the major jurists of Najaf through Grand Ayatollah Khu'i, Sistani's immediate predecessor, go into great detail in their treatment of marriage on the rules respecting marriage to, and intercourse with, female slaves. ${ }^{230}$ Hence, where Sistani speaks in the passage set forth in Part III.B as marriage ${ }^{231}$ being "of two

225 Hence, for example, Barry Friedman indicates that in its rulings across two centuries, the Supreme Court has largely adopted constitutional understandings that conform to popular expectations, and that its legitimacy has suffered when it has failed to do so. Barry Friedman, The Will of the People: How Public Influence Has Influenced the Supreme Court and Shaped the Meaning of the Constitution 9-15 (Farrar et. al. eds., 2009).

226 JAWAHIR, supra note 51, 29:172-73, 182; HAKIM, supra note 128, 14:433-34.

227 SisTANI, supra note 51, at 3: $₫ 60$.

228 See supra Part II.C.i.

229 See supra notes 61-75 and accompanying text.

230 It is important to note that slavery historically appears in far more sections than the book of marriage. There is an entire section, or "book," devoted to manumission, for example. See generally, e.g., JAWAHIR, supra note 51, 34:86-193. Even more prominently, the Book of Sale in almost any Sunni or Shi'i juristic compendium written prior to the twentieth century contains extensive rules respecting the purchase or sale of human beings. See ALI, supra note 6, at 7 (pointing out the usefulness to medieval jurists of using slaves as examples in commercial transactions). As these bear less direct of a connection to matters of personal status, I do not discuss them in the main text.

231 Supra note 101 and accompanying text. The term $I$ have translated here as "licit sexual intercourse" is nikah, which is the same word Sistani uses and which I refer to generally as "marriage." The translation of nikah as marriage is largely accurate but an important nuance arises in the context of slavery. Specifically, nikah can include 
types," Khu'i instead lists three types of licit sexual intercourse. ${ }^{232}$ In addition to permanent marriage and temporary marriages, there is also "the ownership of the right hand," meaning intercourse with slaves. ${ }^{233}$ An entire section follows shortly thereafter entitled "on the permissibility of enjoying female slaves and licit sexual intercourse with them." 234 This is in addition to countless other references to slavery and personal status within the compendium, from the inability of an owner of two female slaves who are sisters to enjoy intercourse with both of them so long as he continues to own both ${ }^{235}$ to rules concerning the attribution of children of slaves to their masters under circumstances where the slave has (unlawfully) endured intercourse with more than one man. ${ }^{236}$ Khu'i's treatment is common; nearly every Shi'i juristic text prior to his contains broad and extensive rules concerning when a slave may be married, when she may be "enjoyed" and the rules and conditions for each. ${ }^{237}$

Sistani's texts lack all such references, containing rules only as they concern free people. Is this then an implicit rebuke to Khu'i, and a rejection of the longstanding rules within the shari' $a$ concerning marriage and slavery? It would certainly be encouraging to think so. However, Sistani appears to be doing something else. He seems to want neither to cast aside the extensive and thorough rules of slavery set forth by his predecessors, nor to repeat them given both their irrelevance and their potential for subjecting him, and the clerical academies generally, to criticism for endorsing a practice broadly regarded as abhorrent in the modern era among liberals and conservatives alike.

He thus indicates he will not address slavery, but does so in a notably oblique fashion. Following a rule in which he declares the birth control practice of withdrawal as permissible, if reprehensible, the following footnote appears:

This is the rule for a free woman, but for a female slave withdrawal from her is permitted absolutely, and without it being reprehensible. It should be noted that the subject of the rules mentioned in this book are for free men and women. As for the male and female slave, they differ from this in some of their rulings. We have omitted - for the most part-laying out their rules because we are not afflicted with it in this era. ${ }^{238}$

permissible forms of intercourse beyond those of permanent and temporary marriage, and in particular sex with female slaves. Hence, in this specific context alone, I refer to nikah as "licit sexual intercourse" rather than "marriage" even though ordinarily, and certainly in modern parlance, it is understood to be virtually synonymous with marriage.

232 KHU'I, supra note 68, at 2:257.

$233 \quad I d$.

234 Id. at $91320-40$

235 Id. at 91255

236 Id. at $\lceil 1374$

237 See, e.g., HAKIM, supra note 128, at 14:278-367 (containing extensive rules of marriage as they pertain to slaves); JAWAHIR, supra note 51, 30:202-314.

238 SISTANI, supra note 51, at 3: $\uparrow 10 \mathrm{n} .1$. 
There are several matters of significance to note. The first is that of all places to include the reference to the omission of slavery, this is possibly among the most obscure. The more logical place would be later, when discussing the three types of licit sexual intercourse that exist within the juristic rules. This seems an effort to bury the information.

Second, even if a person finds the footnote, they are unlikely to pay it much heed. A seminary student attached to juristic tradition is led to think this is a mere nod to practicality. By contrast, it will mean nothing to a social conservative for whom slavery is not a current practice, and even a critic might only glance at the information without much thought. The permissibility of sex with the slave is oblique, after all, and only in the context of a relatively harmless rule relating primarily to birth control.

Finally, while Sistani's purported explanation for omitting the rules concerning the "enjoyment" of female slaves may seem defensible at first glance, in fact in broader context it hardly seems so. After all, the marriage of six-yearolds has been illegal in Iraq for decades as well under the existing Personal Status Code, and yet Sistani mentions the rules respecting that practice in ample detail. ${ }^{239}$ In addition, Sistani's rules concerning the payment of blood money are not recognized in Iraqi law either, and yet again, he continues to mention them, and the drafters of the Ja'fari Code replicate that rather than dismiss it as irrelevant in our times. ${ }^{240}$ Sistani even has a rule permitting a woman to invalidate her marriage to a husband if, after she contracts it, she learns that he has been castrated. ${ }^{241}$ In a world of harems and eunuchs, this may have been relevant, but it is hard to believe that this happens with any frequency today at all. If the touchstone for what is and is not to be mentioned in the juristic rules is purely relevance, then there is much that requires excision.

Rather, Sistani seems to be engaging in strategic juristic omission. In other words, he is deferring to the expectations of his constituency in what he chooses to mention and to omit. As noted above, child marriage exists in Iraq within Shi'i conservative communities. If Sistani refused to discuss it on the grounds that marriage of minors is a matter with which we are "not afflicted" in this era, it would be both counterfactual and harmful to his status as Najaf's premier jurist. It would seem to privilege Iraqi law over Shi'i practice in a manner that many conservative Shi'a might find objectionable. By contrast, because the

239 Compare SISTANI, supra note 51, 3: ๆ8 (indicating no intercourse with girls under nine); $\$ 59$ (granting father and paternal grandfather the power to contract marriage for a minor) with Personal Status Code No. 188 of 1959 (Iraq) at arts. 7 ("The conditions for competency to marry are sanity and the completion of eighteen years") and $9(1)$ ("No relative or anyone else has the right to force any person, male or female, to marry without their permission.").

240 See supra note 226 and accompanying text (quoting the draft Code's references to blood money).

241 SISTANI, supra note 51, 3: $\llbracket 268(2)$. 
modern principles underlying the abolition of slavery have largely been internalized across the Iraqi political spectrum, ${ }^{242}$ the deference to Iraqi law in its abolition of slavery is sensible. It meets with no objections among Sistani's core conservative constituency, and avoids miring him in matters that could lead to broad international condemnation.

When the matter is slavery, it is nearly impossible for a Grand Ayatollah to be anything but explicit in noting omissions. The rules on sex with slaves are too extensively laid out, in far too much detail, and over too many sources, ${ }^{243}$ to be able to exclude them without some sort of explanation. To pretend they do not exist would strain the credulity of anyone even faintly familiar with juristic texts.

In other cases, the discrepancies are subtle enough that it is hard to know whether what is taking place is strategic juristic omission, as with slavery, or the reaching of a different conclusion concerning the source text, as with Sistani's rules concerning the right of a girl to disavow a marriage at puberty. ${ }^{244}$ It is not clear, for example, whether Grand Ayatollahs Khu'i and Sistani disagree with an earlier primus inter pares Grand Ayatollah of Najaf, Muhsin al-Hakim, in his determination that it is recommended to imprison a wife in her home, so that she does not leave except when necessary. ${ }^{245}$ Neither recounts the rule, nor do they recount Hakim's stated recommendation that there be haste in setting a marriage for a woman once she does reach the age of nine because it is better for a girl not to menstruate in her father's home. ${ }^{246}$ This may reflect strategic omission, and there would be good reason for it. After all, very devout women do frequently leave the home in modern Iraq. Indeed the much-heralded sister of one prominent cleric spent a great deal of time promoting modern Islamist notions among women and lost her life in 1980 because of it. ${ }^{247}$ It is one thing to indicate she requires her husband's permission to do this, as Sistani and Khu'i both do. ${ }^{248}$ It is quite another to say it is preferable that she remain locked in her home, as Hakim does. ${ }^{249}$ Similarly, while some Iraqis do marry their daughters at nine, a good many do not, and would not appreciate being told it would be favored if they did.

242 Freamon properly notes that there is a broad condemnation of the practice of slavery in contemporary Muslim societies. Bernard K. Freamon, Slavery, Freedom, and the Doctrine of Consensus in Islamic Jurisprudence, 11 HARV. HUM. RTS. J. 1, 7 (1998). As Freamon noted then, and as is even truer now, there is some number of groups who continue to engage in and defend the practice of slavery, but the consensus remains firmly against the practice. See $i d$. at 5-6.

243 See supra note 240 and accompanying text.

244 See supra notes 140-42 and accompanying text (referring to Sistani's rule and its variance from existing juristic precedent).

245 HAKIM, supra note 128 , at $14: 11$.

246 Id.

247 Joyce Wiley, Alima Bint al-Huda: Women's Advocate, in THE Most LeARnEd of THE SHI'A: THE INSTITUTION OF MARJA’ TAQLID 149-50, 157 (Walbridge ed. 2001).

248 See SISTANI, supra note 51, at 3: ๆ337; KHU'I, supra note 68, at 2: ๆ1407.

249 HAKIM, supra note 128 , at 14:11. 
At the same time, these positions are not so deeply and broadly established in Shi'i texts that one could discount the possibility that Sistani and Khu'i reached different legal conclusions from that of Hakim rather than exercised strategic juristic omission. That those conclusions could have been driven by the social and political circumstances described in the previous paragraph is obvious, but nevertheless, they would hardly be an example of strategic juristic omission if they were indeed the result of a different interpretation of authoritative texts.

The most interesting cases, however, lie between the poles of slavery on the one hand, where omission is necessarily explicit, and recommendations respecting the imprisonment of wives on the other, where there may not even be omission so much as doctrinal evolution. These are the cases where the source material is extensive enough that one would expect overt treatment of a subject that the jurist is ignoring, but not so extensive that the jurist is forced to acknowledge the fact that he has omitted a longstanding rule. The resulting silence is a form of deference to modern socially conservative expectations, even at the expense of altering contemporary understandings of the firmly established doctrine. However, it is done in an indirect manner that avoids the jurist having to explain the basis for his actions. An excellent example of this concerns the subject of female genital mutilation, as described further below.

\section{B. On Strategic Juristic Omission and Female Genital Mutilation}

Female genital mutilation has significant pedigree within historic Shi'i doctrine. A reasonably extensive treatment of the subject can be found in the Jawahir, as follows:

As for females, it is referred to among the companions as "the curtailing of the maidens" and it is "recommended" without disagreement. To the contrary, the consensus supports it, and the [original] sources are plentiful or incontrovertible, and present the matter in its entirety. It is not required for the guardian [to do] before puberty, nor incumbent upon [the maidens] after it. The manifest opinion is that the time for them is seven years [after adulthood; i.e. the age of 16]. Indeed based on the report of Giyath ibn Ibrahim from Ja'far ibn Muhammad [al-Sadiq] from his father [Muhammad al-Baqir], peace be upon the latter two of them, "do not curtail the maiden until she is an adult seven years."

It is required not to uproot it in its entirety. From the Sahih of Ibn Muslim, from Abi Abdillah (peace be upon him), when the women emigrated to the Apostle of God (peace be upon him), a woman emigrated with them who was called "Um Habeeb," and 
she was a curtailer, who curtailed maidens. When the Apostle of God, peace be upon him, saw her, he [peace be upon him] said to her, "Um Habeeb, the work that you used to do, do you do it now?" She said to him [peace be upon him], "Yes, Apostle of God, unless it is forbidden, and you tell me to avoid it." So he said, "No, it is permissible. Come near me, so I may teach you." She neared him, and he said, "Um Habeeb, if you do it, then do not destroy and do not remove entirely, but mark it, for this brightens the face and is more pleasurable for the husband."

"And" in any event what is clear from what we have mentioned is that "if an uncircumcised nonbeliever becomes a Muslim, he must circumcise" himself "if he was of old age. . . and" it is clear also that "if a woman becomes a Mustim" then "she is not obligated to be circumcised" but that is "recommended" for her. In the report of Abi Basir, "I asked the father of Ja'far, peace be upon him, about the maiden who comes from the land of polytheism and she becomes Muslim, and she asks for one to curtail her, but she is unable to find a woman [to do it], so he said, 'The Sunna [i.e. the practice of the Prophet and the Imams] for circumcision is for men, and not for women.",250

This is the main passage that addresses the question of female genital mutilation in a compendium that spans 43 volumes. Thus, unlike slavery, the references to it are not extensive in the historic juristic texts, nor are they repeated with frequency. That said, the passage is detailed enough to make clear that the traditional juristic position in favor of female genital mutilation is a reasonably well established one. It appears, after all, in one of the most influential compendia of the nineteenth century, which is the subject of intense study in the seminaries of Najaf today ${ }^{251}$ and which is itself an extended commentary of one of the most influential juristic works in the history of Shi'ism, the thirteenth century Shara' $i$ al-Islam of Muhaqqaq al-Hilli. ${ }^{252}$ Moreover, the passage describes the original source material upon which the opinion is based as at the very least "plentiful" (mustafidha) if not so well established as to be "incontrovertible" (mutawatir). ${ }^{253}$

250 JAWAHIR, supra note 51, at 31:262-63 (emphasis and quotation marks retained from Al-Hilli's original text, discussed infra).

25l See Abdulaziz Sachedina, The Just Ruler IN Shi'ite Islam: The COMPREHENSIVE AUTHORITY OF THE JURIST IN IMAMITE JURISPRUDENCE 22 (1988) (describing the influence of the Jawahir). For a less sober and academic account, one popular website describes the Jawahir as "an indispensable companion of every [jurist] worth any name, since each line in it requires profound pondering and elucidation [sic]." Allamah Shaikh Muhammad Hasan Najafi 'Sahib-e-Jawahir,' IMAM REZA NETwORK, http://www.imamreza.net/eng/imamreza.php?id=6934 (last visited Mar. 26, 2016).

252 SACHEDINA, supra note 251 , at 14.

253 JAWAHIR, supra note 51, 31:262. 
It does not obligate women to have their genitalia mutilated, but it does indicate that to do so would be a religiously recommended act. ${ }^{254}$

At the same time, the practice of female genital mutilation is extremely rare, if not entirely absent, amongst the Arab Shi'a in Iraq. ${ }^{255}$ There is no expectation for women to undergo the procedure. ${ }^{256}$ To demand something so alien, or even to recommend it, is to risk alienating an important constituency that regards juristic dictates as important.

It therefore comes as little surprise that modern jurists do not call attention to the historic rule respecting female genital mutilation, and indeed have begun to engage in strategic juristic omission with respect to it. They have not, to reemphasize the point, reexamined the source material to challenge the conclusions of the 19th century Jawahir, nor those of Muhaqqiq al-Hilli upon which it is based. Nowhere do they challenge, for example, the conclusion of the Jawahir that the original source material leads to an "incontrovertible" conclusion recommending female genital mutilation, nor do they offer a different understanding of precisely what the Prophet Muhammad was saying to Umm Habeeb, and what lessons might be drawn from it. Such approaches might be eminently plausible, to be clear, but those are the methods of the liberal and the reformer, not those of the traditionalist seminaries who currently pronounce Shi' $i$ doctrine. Instead, the authorities over time reduced the rule, and ultimately stopped referring to it entirely, without at any point in the process ever challenging its legitimacy.

The process of reduction, and indeed prevarication, begins with Grand Ayatollah Khu'i. His compendium reflects the rule, but in so reduced a form that it effectively changes its meaning. Khu'i specifically states as follows:

It is recommended to wash the newborn and read the call to prayer in his right ear, and the preparation for prayer ( 'iqama) in the left, to place the earth of Husayn, peace be upon him, in his mouth, mixed with the water of the Euphrates, ${ }^{257}$ and name him with a name of one of the Prophets or Imams, peace be upon them, and giving him a nickname (but not to nickname a Muhammad with "Abi Qasim), ${ }^{258}$ to shave his head on the

254 Id.

255 Ian Black \& Fazel Hawramy, ISIS Denies Ordering That All Girls in Mosul Undergo FGM, THE GUARDIAN (July 24, 2014) (quoting an Iraqi newspaper to the effect that "the practice of FGM is alien to Iraqi society except the Kurdish provinces").

256 See id. (noting total absence of FGM in Iraq outside of the Kurdish areas).

257 Perhaps the central legend around which Shi'ism is based is the death of Husayn bin Ali, the grandson of the Prophet Muhammad, in the plains known today as Kerbala along the banks of the Euphrates River. MOMEN, supra note 47, at 30-31. Hence the juristic rule that recommends that a child upon birth first taste the earth of Kerbala, mixed with the water of the Euphrates.

258 The Prophet Muhammad is referred to as "Abi Qasim," or father of Qasim, because this was the name of his first born son. TARIQ RAMADAN, IN THE FOOTSTEPS OF THE 
seventh day, and a celebration afterwards, to give as charity the weight of his hair in gold or silver, to pierce his ear and circumcise him, and circumcision is obligatory after puberty if he has not been circumcised earlier. The curtailing of the maidens is recommended, even if they reach adulthood, but the preference is seven years after their adulthood. ${ }^{259}$

In the first place, it is quite notable that as with Sistani in his rules respecting slavery, ${ }^{260} \mathrm{Khu}$ 'i clearly attempts not to bring very much attention to this rule respecting the mutilation of female genitalia. It is buried in a series of other rules, most of which plainly pertain exclusively to boys, such as circumcision on the seventh day, and naming the child with the name of a Prophet or Imam. It is only at the end of this litany of recommended acts that Khu'i makes reference to the "curtailment of the maidens."

The reduction of the broader treatment in the Jawahir is also interesting because the term used for "maidens" (jawari in Arabic) could also very likely mean "slave girls," as it commonly does. ${ }^{261}$ Clearly the term does not always mean that. Section II.B above includes a passage of a temporary marriage to a "maiden" who demands a dower in advance, and as slaves could not marry without permission of their master, the implication appears to be that she is free.

More importantly, the "curtailment" is plainly not restricted to female slaves in the Jawahir. Indeed, the passage itself refers to the "circumcision" of females $^{262}$ (after similar passages relating to the circumcision of males), ${ }^{263}$ and indicates that this practice of "female circumcision" has been referred to historically as "curtailment of the maidens." The final paragraph, respecting female genital mutilation for a converted Muslim, refers specifically to it being recommended for "a woman" (mar'a) but not required. ${ }^{264}$ An earlier passage indicates the circumcision of men as being obligatory because it was a tradition of the Prophet, while the "circumcision" of "women" (nisa') is merely "noble" and therefore recommended rather than required. ${ }^{265}$

Yet reviewing Khu'i's considerably reduced rules alone without the benefit such careful, extended treatment hardly leaves the same impression. The matter might very well seem to have something to do with female slaves, but not free women. After all, Khu'i does set out the rules concerning female slaves in

PROPHET: LesSONS FROM THE LIFE OF MUHAMMAD $219 \mathrm{n} .8$ (2007). As a result, the nickname is deemed inappropriate for a person named Muhammad according to Khu'i.

259 KHU'I, supra note $68, \Upsilon 1372$.

260 See supra notes 241-45 and accompanying text.

261 Hence, for example, Khu'i refers elsewhere to obligations on a person who "purchases a maiden." KHU'I, supra note 68, $\$ 1336$.

262 JAWAHIR, supra note 51, at $31: 262$. The specific term is anath, which unmistakably refers to all females.

$263 I d$. at 31:260-62.

$264 \mathrm{Id}$.

265 Id. at 261. 
some level of detail, and this could be considered a more extended part of that analysis. ${ }^{266}$ The term used for "female slave" ( $a m a$ ) is different than the word "maiden" used in the context of "curtailment," but one not predisposed to believe that Shi'ism endorses the mutilation of female genitals might not dwell long on the curious discrepancy.

Several decades later, Khu'i's successor as primus inter pares in Najaf, Grand Ayatollah Sistani, removed all mention of curtailment of the maidens. This might lead a reader to confirm in their mind that indeed the recommendation in favor of female genital mutilation related only to slave girls. After all, as discussed above, Sistani explicitly states that he will not discuss slavery given its lack of relevance. ${ }^{267}$ That earlier, authoritative jurists had found it near incontrovertible that mutilating the genitalia of all females was recommended at the age of sixteen is then left well-disguised. In fact, it is so well disguised that few to none of the socially conservative Shi'a dominating Iraq's south would have any reason to know the actual rule, which reflects values that clearly are not present in their own society. ${ }^{268}$

Of course, any legislator has a very easy time conforming a draft law such as the Ja'fari Personal Status Code to modern, socially conservative expectations in cases of strategic juristic omission. The legislator need only follow the lead of the jurist who has already done the work of masking parts of the doctrine to meet social demands. All references to slavery can be omitted, as well as recommendations to imprison women and mutilate their genitals. If anyone were to ask precisely why the legislator had done this, the legislator need only hand the person making the objection a copy of Sistani's compendium and ask where such rules appear such that they require recognition in law. The mask thus works, and the distortion necessary to conform traditional rules to conservative expectations is complete.

It is therefore of little to no surprise that the draft Code does not recommend genital mutilation and omits all rules concerning the enjoyment of female slaves. That does nothing, however, to evade the central fact that such rules are very much part of the Shi'i tradition. If the drafters truly wanted a Code that would replicate the tradition, as was claimed, such rules should be present. A jurist finding it prudent not to talk about such matters is hardly a reason to ignore them in light of the supposed overarching goal of the law. If, however, the real aim of the draft has nothing to do with realizing traditional rules, but instead is an effort to enact something that meets with the expectations and desires of Muslim social conservatives, then of course there is much advantage in using the juristic cover already provided.

\footnotetext{
266 KHU'I, supra note 68, ๆ1320-40.

267 See supra notes 241-45 and accompanying text.

268 See Black \& Hawramy, supra note 255.
} 


\section{CONCLUSION}

This Article has shown that the perceived equivalence between social conservatism in the Muslim world and adherence to traditional religious rules is a false one. The point is not that social conservatives ignore religious rules entirely, any more than liberals do. Rather, they apply such rules selectively, manipulating and reformulating them in a process and in a manner that suits a preexisting ideological vision that seeks the preservation of existing social hierarchies and authorities. This is not terribly different in the end from the methods of the liberal, even if the liberal's aims involve the realization of a very different social and religious order from those of the social conservative.

However, it is worth noting in these final paragraphs that the persistence of the equivalence between Islamic social conservatism and adherence to religious rules is not only false, it is also positively dangerous in the large part of the world where the central role of Islam in establishing legal order is rarely questioned. ${ }^{269}$ So long as Islam retains this position, then there is very clearly a problem with attributing the preferences of social conservatives to the realization of "strict" shari" $a$, while describing those of Muslim liberals as "reformist." The social conservative is then seen as pure, and unmotivated by any ideological, political or social concerns beyond those of faithfully fulfilling God's Will. Pursuant to this vision, it is not that the Minister of Justice, ${ }^{270}$ or at least the core constituency whose support he courts, wants fathers to be able to marry their infant daughters to middle aged men who will "thigh" them. ${ }^{271}$ It is that God deems it permissible, and the Minister can do no more than humbly and piously do His Will.

Yet as we have seen, the Code almost entirely ignores a rather central part of Shi'i marriage doctrine, and one discussed at some length by jurists across the span of centuries. This is the "temporary marriage," where one contracts with a woman to marry her for a short span of time, with the barter being explicitly the trade of money, in the form of a dower, for sexual enjoyment. ${ }^{272}$ In the absence of any set of rules governing the practice in the Draft Ja'fari Code, it would appear to fall within the definition of prostitution under Iraqi law, a crime that is punishable

269 To give a sense of the considerable popularity of Islam generally, and the shari' $a$ particularly, as a source of legal order, the Pew Research Center undertook a broad and extensive survey in 2013 respecting attitudes religion, politics and society in the Muslim world. The study showed that "[o]verwhelming percentages of Muslims in many countries want Islamic law (sharia) to be the official law of the land." The World's Muslims: Religion, Politics and Society, Pew Research Center: Religion AND Public LIfE (Apr. 30, 2013), http:/www.pewforum.org/2013/04/30/the-worlds-muslims-religion-politicssociety-overview/.

270 See supra note 46 and accompanying text (describing the role of the Minister of Justice in promulgating the Draft Ja'fari Code).

271 See SISTANI, supra note 51, 3: \8; HAKIM, supra note 128, at 14:79-80. See also supra notes 145-46 accompanying text.

272 See supra Part II.B. 
by life imprisonment. ${ }^{273}$ In other words, in Iraq today, a woman could go to jail for life for agreeing to be sexually available to a man for an hour in exchange for a sum of money, even though the jurists specifically permit this practice. The draft Code does nothing to change that result.

One could imagine a different result: a libertarian one that imposed life imprisonment on anyone performing any sort of sexual act with a child, but legalized a temporary marriage between consenting adults. It is hardly obvious that, were it ever advocated, it would represent a more radical departure from juristic rules than the draft Code, which legalizes child marriage and leaves temporary marriage illegal and subject to harsh punishment. There is no reason to call one of these approaches "pure" or "literal" while describing the other as "reformist." To do so would delegitimize the libertarian approach as the contamination of doctrine while also sanctifying the sociall conservative one as somehow in close adherence to it. This leaves the content of the shari'a in the firm grip of social conservatives, and makes meaningful reassessment of the doctrinal tradition in a more progressive direction all the harder to achieve.

In the end, the debate is hardly about literal adherence to any doctrine, as nobody is really attempting that. It is instead about ideological preferences. Do we seek an Islam that recognizes the inherent worth of the individual, grants individuals the freedom to make their own decisions respecting matters such as marriage and religion, seeks to protect disadvantaged groups from discrimination, and permits and protects challenges to existing hierarchies and modalities of authority? Or do we prefer a preservation of those existing hierarchies and modalities, so that men control the lives of women, fathers control the lives of children, tribes control the lives of their members, and each has the duty to obey those in authority over them? Neither is more literal nor more faithful to any preexisting doctrine. The doctrine is merely the mask. It is beyond time to rip it off.

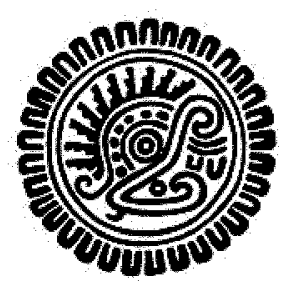

273 Prostitution was punishable by death until 2003, when the death penalty was suspended and replaced by life imprisonment. Revolutionary Command Council Decree No. 234 of 2001 (Iraq), at art. 3, http://gipi.org/wp-content/uploads/rcc-resolution-234-of2001.pdf as amended by Coalition Provisional Authority Order 7, at art. 3(1) (June 10, 2003). 